\title{
Structure and Dynamics of Heterometallic Clusters Derived from Addition of Metal Carbonyl Fragments to the Unsaturated Hydride $\left[\mathrm{W}_{2} \mathrm{Cp}_{2}(\mu-\mathrm{H})\left(\mu-\mathrm{PPh}_{2}\right)(\mathrm{NO})_{2}\right] \dagger$
}

\author{
M. Angeles Alvarez, M. Esther García, Daniel García-Vivó,* Miguel A. Ruiz,* and \\ Adrián Toyos.
}

Departamento de Química Orgánica e Inorgánica/IUQOEM, Universidad de Oviedo, E-33071 Oviedo, Spain.

\begin{abstract}
The title complex reacted with $\left[\mathrm{Fe}_{2}(\mathrm{CO})_{9}\right]$ to give the trinuclear derivative $\left[\mathrm{FeW}_{2} \mathrm{Cp}_{2}(\mu-\right.$ $\left.\mathrm{H})\left(\mu-\mathrm{PPh}_{2}\right)(\mathrm{CO})_{4}(\mathrm{NO})_{2}\right](\mathrm{W}-\mathrm{W}=3.044(1) \AA)$ as a result of full insertion of the 16electron $\mathrm{Fe}(\mathrm{CO})_{4}$ fragment into the tricentric $\mathrm{W}-\mathrm{H}-\mathrm{W}$ bond of the parent substrate. In contrast, the reactions with the THF adducts $\left[\mathrm{M}(\mathrm{CO})_{5}(\mathrm{THF})\right](\mathrm{M}=\mathrm{W}, \mathrm{Mo})$ and $\left[\mathrm{MnCp}(\mathrm{CO})_{2}(\mathrm{THF})\right]\left(\mathrm{Cp}^{\prime}=\mathrm{C}_{5} \mathrm{H}_{4} \mathrm{Me}\right)$ yielded the $\mu_{3}$-hydride derivatives $\left[\mathrm{MW}_{2} \mathrm{Cp}_{2}\left(\mu_{3}-\right.\right.$ $\left.\mathrm{H})\left(\mu-\mathrm{PPh}_{2}\right)(\mathrm{CO})_{5}(\mathrm{NO})_{2}\right]\left(\mathrm{W}-\mathrm{W}=3.006(1)\right.$ to $3.164(1) \AA$ for the $\mathrm{W}_{3}$ compound $)$ and $\left[\mathrm{MnW}_{2} \mathrm{Cp}_{2} \mathrm{Cp}^{\prime}\left(\mu_{3}-\mathrm{H}\right)\left(\mu-\mathrm{PPh}_{2}\right)(\mathrm{CO})_{2}(\mathrm{NO})_{2}\right]$ respectively, all of them resulting from addition (rather than insertion) of the corresponding 16-electron fragment to the $\mathrm{W}_{2} \mathrm{H}$ moiety of the parent compound. Density Functional Theory calculations revealed that edge- and face-bridged hydride clusters were of similar energy in the $\mathrm{W}_{2} \mathrm{Fe}$ system, while the face-bridged structure was significantly more stable (by more than ca. 40 $\mathrm{kJ} / \mathrm{mol}$ ) for the $\mathrm{W}_{3}$ system. Both clusters displayed fast rearrangement in solution involving a flapping movement of the puckered $\mathrm{PW}_{2} \mathrm{M}$ core of these molecules. This was combined, in the $\mathrm{W}_{2} \mathrm{Fe}$ cluster, with fast exchange between the almost isoenergetic edge- and face-bridged hydride isomers. The reactions of the title compound with several carbonyl dimers were also examined as an additional synthetic approach to the rational synthesis of heterometallic clusters, but were unsuccessful except in the case of $\left[\mathrm{Co}_{2}(\mathrm{CO})_{8}\right]$, which reacted at $253 \mathrm{~K}$ in the dark to give a mixture of the binuclear complex $\left[\mathrm{CoWCp}\left(\mu-\mathrm{PPh}_{2}\right)(\mathrm{CO})_{4}(\mathrm{NO})\right](\mathrm{Co}-\mathrm{W}=2.8623(6) \AA)$ and the trinuclear cluster $\left[\mathrm{CoW}_{2} \mathrm{Cp}_{2}\left(\mu-\mathrm{PPh}_{2}\right)(\mathrm{CO})_{4}(\mathrm{NO})_{2}\right](\mathrm{W}-\mathrm{W}=3.1654(4) \AA ; \mathrm{W}-\mathrm{Co}=2.638(1), 2.829(1) \AA)$, the latter resulting from formal replacement of the hydride ligand with the 17-electron fragment $\mathrm{Co}(\mathrm{CO})_{4}$, which displayed an asymmetric binding to the $\mathrm{W}_{2}$ centre.
\end{abstract}




\section{Introduction}

Heterometallic clusters are species of general interest not only because of their structures and bonding, but also because of the impact that the presence of the intrinsically polar heterometallic $\mathbf{M}-\mathbf{M}^{\prime}$ bonds may have on their general reactivity, including catalytic activity, and even as precursors of heterometallic nanoparticles. ${ }^{1}$ The synthesis of these species, however, often is not a straightforward matter, and the implementation of rational and efficient preparative routes remains a valuable target in the field. In the case of organometallic compounds, one of the most successful routes to access this sort of clusters relies on reactions of complexes bearing $\mathrm{M}-\mathrm{M}$ multiple bonds (which effectively behave as building clocks) with precursors of different metal fragments, as exemplified by the extensive work carried out previously on species having a 32-electron $\mathrm{M}_{2}(\mu-\mathrm{H})_{2}$ core, such as $\left[\mathrm{Os}_{3}(\mu-\mathrm{H})_{2}(\mathrm{CO})_{10}\right],{ }^{2}\left[\mathrm{Re}_{2}(\mu-\mathrm{H})_{2}(\mathrm{CO})_{8}\right],{ }^{3}$ and $\left[\mathrm{Mn}_{2}(\mu-\mathrm{H})_{2}(\mathrm{CO})_{6}\left(\mu-\mathrm{L}_{2}\right)\right],{ }^{4}$ or binuclear cyclopentadienyl complexes bearing $\mathrm{M}-\mathrm{M}$ triple bonds. ${ }^{5}$ The results of these reactions can be often rationalized in the light of the isolobal analogies, which thus produce an useful roadmap for the rational synthesis of such heterometallic molecules. ${ }^{6}$

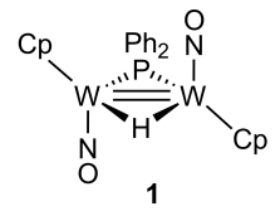

\section{Chart 1}

Recently we reported the preparation of the unsaturated nitrosyl hydride $\left[\mathrm{W}_{2} \mathrm{Cp}_{2}(\mu-\right.$ $\mathrm{H})\left(\mu-\mathrm{PPh}_{2}\right)(\mathrm{NO})_{2}$ ] (1), a 32-electron complex related to the dihydride complexes mentioned above and stabilized with respect to degradation into mononuclear derivatives thanks to the presence of the robust phosphanyl ligand bridging the tungsten atoms (Chart 1). ${ }^{7}$ We then decided to check the potential of $\mathbf{1}$ as precursor of heterometallic clusters bearing nitrosyl and carbonyl ligands by examining its reactions with different transition metal carbonyl complexes, which is the purpose of the present paper. Interest in heterometallic clusters bearing both $\mathrm{NO}$ and $\mathrm{CO}$ ligands stems from several observations of full cleavage of the robust NO ligand at heterometallic carbonyl complexes bearing two, ${ }^{8}$ three ${ }^{9}$ and four metal atoms, ${ }^{10}$ a process of general interest in the context of the continuous search for new and more efficient catalysts for $\mathrm{NO}_{\mathrm{x}}$ abatement. $^{11,12}$ As it will shown below, the reactions of $\mathbf{1}$ with different carbonyl complexes lead to heterometallic trinuclear derivatives via two different reaction pathways, one of them retaining the bridging hydride ligand, which turned out to display a high mobility over the metal core of these clusters, analyzed with the help of Density Functional Theory (DFT) calculations. 


\section{Results and Discussion}

\section{Reactions of 1 with precursors of 16-electron metal fragments}

Compound 1 reacts readily with $\left[\mathrm{Fe}_{2}(\mathrm{CO})_{9}\right]$, a well-known precursor of the 16-electron fragment $\mathrm{Fe}(\mathrm{CO})_{4}$, in toluene at room temperature to give the corresponding trinuclear derivative $\left[\mathrm{FeW}_{2} \mathrm{Cp}_{2}(\mu-\mathrm{H})\left(\mu-\mathrm{PPh}_{2}\right)(\mathrm{CO})_{4}(\mathrm{NO})_{2}\right]$ (2) in good yield, which follows from full insertion of the iron fragment into the tricentric $\mathrm{W}-\mathrm{H}-\mathrm{W}$ bond of the parent substrate (Scheme 1). In contrast, the reactions of $\mathbf{1}$ with the THF adducts $\left[\mathrm{M}(\mathrm{CO})_{5}(\mathrm{THF})\right]$ and $\left[\mathrm{MnCp}(\mathrm{CO})_{2}(\mathrm{THF})\right]\left(\mathrm{Cp}^{\prime}=\eta^{5}-\mathrm{C}_{5} \mathrm{H}_{4} \mathrm{Me}\right)$ in toluene solution also proceeded rapidly at room temperature, but yielded the corresponding $\mu_{3}$-hydride derivatives $\left[\mathrm{MW}_{2} \mathrm{Cp}_{2}\left(\mu_{3}-\mathrm{H}\right)\left(\mu-\mathrm{PPh}_{2}\right)(\mathrm{CO})_{5}(\mathrm{NO})_{2}\right] \quad(\mathrm{M}=\mathrm{W}$ (3), Mo (4)) and $\left[\mathrm{MnW}_{2} \mathrm{Cp}_{2} \mathrm{Cp}^{\prime}\left(\mu_{3}-\mathrm{H}\right)\left(\mu-\mathrm{PPh}_{2}\right)(\mathrm{CO})_{2}(\mathrm{NO})_{2}\right](5)$ respectively, all of them resulting from addition (rather than insertion) of the corresponding 16-electron metal fragment to the $\mathrm{W}_{2} \mathrm{H}$ moiety of the parent compound (Scheme 1). The reactions with the $\mathrm{W}$ and $\mathrm{Mn}$ adducts were accompanied by the formation of small amounts of the electron-precise hydride complex $\left[\mathrm{W}_{2} \mathrm{Cp}_{2} \mathrm{H}\left(\mu-\mathrm{PPh}_{2}\right)(\mathrm{CO})(\mathrm{NO})_{2}\right]$, a product resulting from carbonylation of the unsaturated hydride $1{ }^{7}$, which could be separated from the corresponding clusters upon chromatographic workup. However, the reaction with the Mo adduct yielded a 2:1 mixture of the above hydride and the cluster 4 , the latter being a rather unstable molecule which could not be isolated as a pure solid.

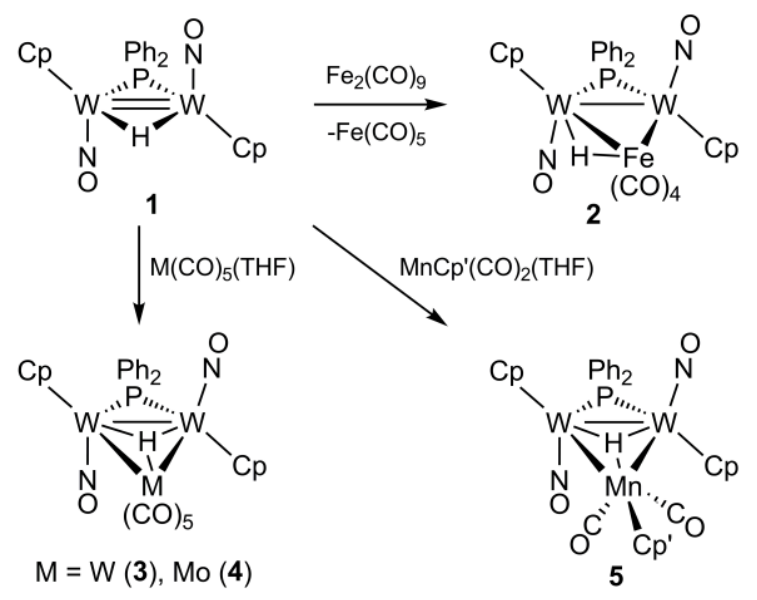

Scheme 1. Addition of 16-electron metal fragments to hydride 1

\section{Solid-state structures of hydride clusters 2 and 3}

The molecule of the $\mathrm{W}_{2} \mathrm{Fe}$ cluster $\mathbf{2}$ in the crystal displays an asymmetric triangular core with significantly different W-Fe lengths of 2.779(3) and 2.914(4) $\AA$ (Figure 1 and Table 1). Although the quality of the diffraction data was not very high, still a hydride ligand could be safely located as bridging the longer W1-Fe edge (see the Experimental Section), a position otherwise consistent with DFT calculations to be discussed later on. The coordination spheres of the metal atoms are completed as expected, with the $\mathrm{W}$ 
atoms displaying the transoid $\mathrm{W}_{2} \mathrm{Cp}_{2}(\mathrm{NO})_{2}$ arrangement already present at the parent hydride $\mathbf{1}$ and the Fe atom bearing four CO ligands in a distorted see-saw configuration, a matter to be discussed in the context of the solution structure of this molecule. The phosphanyl ligand bridges the $\mathrm{W}$ atoms in a rather symmetric way, and the central $\mathrm{PW}_{2} \mathrm{Fe}$ rhombus is not flat, but significantly puckered $\left(\mathrm{P}-\mathrm{W}-\mathrm{W}-\mathrm{Fe}\right.$ ca. $\left.159^{\circ}\right)$; as a result, the terminal nitrosyls no longer are antiparallel to each other (as they were in $\mathbf{1}$ ), but one of them points away from the ditungsten centre (N2-W2-W1 ca. 114 ${ }^{\circ}$ ) while the other one slightly leans over it (N1-W1-W2 ca. 85 $)$. This geometrical distortion is common in related binuclear carbonyl complexes bearing sterically-demanding bridging groups (cf. $\left[\mathrm{M}_{2} \mathrm{Cp}_{2}\left(\mu-\mathrm{PCy}_{2}\right)\left(\mu-\mathrm{SnPh}_{3}\right)(\mathrm{CO})_{2}\right]$, with $\mathrm{P}-\mathrm{M}-\mathrm{M}-\mathrm{Sn}$ puckering angles of ca. $\left.160^{\circ} ; \mathrm{M}=\mathrm{Mo},{ }^{13} \mathrm{~W}\right) .{ }^{14}$

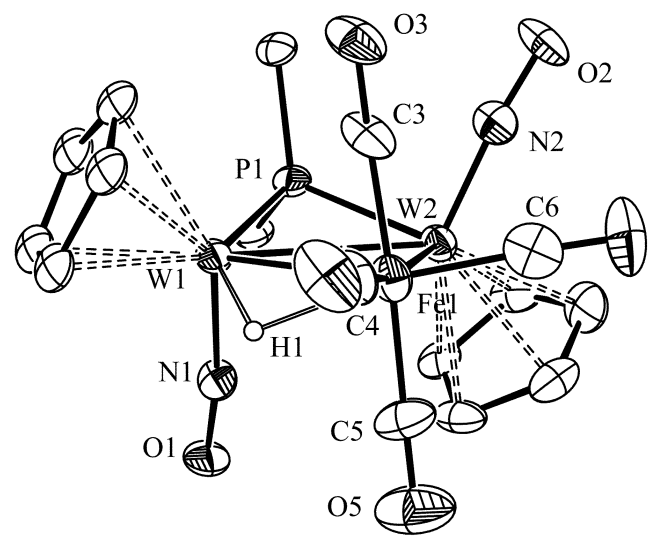

Figure 1. ORTEP diagram (30\% probability) of compound 2, with $\mathrm{H}$ atoms (except the hydride ligand) and $\mathrm{Ph}$ rings (except their $\mathrm{C}^{1}$ atoms) omitted for clarity.

Table 1. Selected bond lengths $(\AA)$ and angles $\left({ }^{\circ}\right)$ for compound 2

\begin{tabular}{llll}
\hline W1-W2 & $3.044(1)$ & W1-P1-W2 & $78.8(2)$ \\
W1-Fe1 & $2.914(4)$ & W1-Fe1-W2 & $64.6(1)$ \\
W2-Fe1 & $2.779(3)$ & P1-W1-N1 & $91.2(5)$ \\
W1-P1 & $2.405(5)$ & P1-W2-N2 & $95.2(7)$ \\
W2-P1 & $2.390(5)$ & P1-W1-H1 & $138(4)$ \\
W1-N1 & $1.81(2)$ & N1-W1-W2 & $85.5(5)$ \\
W2-N2 & $1.76(2)$ & N2-W2-W1 & $114.4(6)$ \\
Fe1-C3 & $1.79(3)$ & H1-Fe1-C4 & $86(5)$ \\
Fe1-C4 & $1.80(3)$ & H1-Fe1-C6 & $168(7)$ \\
Fe1-C5 & $1.76(3)$ & $\mathrm{C} 3-\mathrm{Fe} 1-\mathrm{C} 5$ & $169(1)$ \\
Fe1-C6 & $1.78(3)$ & $\mathrm{C} 4-\mathrm{Fe} 1-\mathrm{C} 6$ & $102(1)$ \\
$\mathrm{W} 1-\mathrm{H} 1$ & $1.84(2)$ & $\mathrm{Fe} 1-\mathrm{C} 3-\mathrm{O} 3$ & $172(2)$ \\
Fe1-H1 & $1.86(2)$ & $\mathrm{Fe} 1-\mathrm{C} 5-\mathrm{O} 5$ & $176(3)$ \\
\hline
\end{tabular}

As noted above, the structure of $\mathbf{2}$ can be viewed as resulting from full insertion of the $\mathrm{Fe}(\mathrm{CO})_{4}$ fragment into the $\mathrm{W}-\mathrm{H}-\mathrm{W}$ bond of $\mathbf{1}$. By recalling that 16-electron $\mathrm{M}(\mathrm{CO})_{\mathrm{x}}$ fragments can be considered isolobal with either a $\mathrm{CH}_{2}$ group or with a $\mathrm{CH}_{3}{ }^{+}$ (or $\mathrm{H}^{+}$) cation, ${ }^{6 \mathrm{a}}$ then we can say that, in the formation of cluster $\mathbf{2}$, the $\mathrm{Fe}(\mathrm{CO})_{4}$ fragment displays a $\mathrm{CH}_{2}$-like behaviour, thus paralleling the reactions of the unsaturated dihydrides $\left[\mathrm{Os}_{3}(\mu-\mathrm{H})_{2}(\mathrm{CO})_{10}\right]$ and $\left[\mathrm{Re}_{2}(\mu-\mathrm{H})_{2}(\mathrm{CO})_{8}\right]$ with $\mathrm{CH}_{2} \mathrm{~N}_{2},{ }^{15,16}$ to yield 
derivatives displaying a 3 -electron donor $\mu-\kappa^{1}: \eta^{2}$-Me agostic ligand. ${ }^{17}$ We note that this behaviour was also observed in the reaction of the dimanganese hydride $\left[\mathrm{Mn}_{2}(\mu-\right.$ $\left.\mathrm{H})_{2}(\mathrm{CO})_{6}\left\{\mu-(\mathrm{EtO})_{2} \mathrm{POP}(\mathrm{OEt})_{2}\right\}\right]$ with $\left[\mathrm{Fe}_{2}(\mathrm{CO})_{9}\right]$, although the structure of the corresponding $\mathrm{Mn}_{2} \mathrm{Fe}$ cluster could not be determined crystallographically at the time. ${ }^{4 \mathrm{a}}$ In electron-counting terms, this behaviour of the Fe fragment provides two additional electrons to the ditungsten centre, which then becomes electron-precise ( 34 electrons), and the same is concluded by considering the overall electron count of $\mathbf{2}$ as a trinuclear cluster (48 valence electrons). Therefore, intermetallic single bonds should be proposed for this molecule, which is in good agreement with the W-W separation of 3.044(1) $\AA$, ca. $0.3 \AA$ longer than the corresponding length in the unsaturated precursor $\mathbf{1}$, and within the range of distances of ca. 2.87-3.10 $\AA$ previously determined for related electron-precise molecules of type $\left[\mathrm{Mo}_{2} \mathrm{Cp}_{2}\left(\mu-\mathrm{PR}_{2}\right)(\mu-\mathrm{X})(\mathrm{NO})_{2}\right](\mathrm{X}=\mathrm{C}-, \mathrm{N}-, \mathrm{P}$-donor, 3-electron ligand). ${ }^{18-20}$ As for the $\mathrm{W}-\mathrm{Fe}$ lengths, we first note that only a few heterometallic Mo or W clusters containing NO ligands have been structurally characterized so far, and even so these are of limited use for comparative purposes, as most of them display bridging NO and CO ligands. Yet, the shorter W2-Fe distance of 2.779 (3) in 2 is only slightly longer than the values of ca. $2.71 \AA$ measured in $\mathrm{MFe}_{2}$ clusters of the type $\left[\mathrm{Fe}_{2} \mathrm{MCp}\left(\mu_{3}-\mathrm{X}\right)(\mu-\mathrm{CO})(\mu-\mathrm{NO})\right]^{\mathrm{n}}(\mathrm{M}=\mathrm{W}, \mathrm{X}=\mathrm{C}-p$ tol, $\mathrm{n}=-1 ; \mathrm{M}=$ Mo, $\mathrm{X}=\mathrm{NH} ; \mathrm{n}=0),{ }^{21}$ but comparable to the $\mathrm{W}-\mathrm{Fe}$ separations of 2.76-2.79 $\AA$ measured in the 46-electron carbonyl cluster $\left[\mathrm{FeMo}_{2} \mathrm{Cp}_{2}\left(\mu_{3}-\mathrm{CPh}\right)(\mu-\mathrm{PCy})(\mathrm{CO})_{5}\right]{ }^{22}$ In contrast, the W1-Fe separation of 2.914(4) $\AA$ is expectedly longer than the above values, due to the presence of the bridging hydride over that edge of the cluster, whereby we must properly speak of a tricentric $\mathrm{W}-\mathrm{H}-\mathrm{Fe}$ interaction in this case, rather than a conventional two-centre $\mathrm{W}-\mathrm{Fe}$ bond. For comparison, the H-bridged $\mathrm{W}-\mathrm{Fe}$ edges in the clusters $\left[\mathrm{Fe}_{2} \mathrm{MCp}(\mu-\mathrm{H})\left(\mu_{3}-\mathrm{E}\right)(\mathrm{CO})_{6}\right]$ span distances in the range 2.91-2.93 $\AA$ ( $\mathrm{M}=\mathrm{Mo}$, $\left.\mathrm{E}=\mathrm{PMoCp}(\mathrm{CO})_{3} ; \mathrm{M}=\mathrm{W}, \mathrm{E}=\mathrm{Se}, \mathrm{Te}\right)^{23}$

The structure of the tritungsten cluster $\mathbf{3}$ can be derived from that of $\mathbf{2}$ after replacing the $\mathrm{Fe}(\mathrm{CO})_{4}$ fragment with the isoelectronic fragment $\mathrm{W}(\mathrm{CO})_{5}$, but the hydride ligand now was successfully located as bridging the triangular metal skeleton, which then becomes a nearly isosceles triangle (Figure 2 and Table 2), in agreement with DFT calculations to be discussed later on. The central heavy-atom skeleton of the molecule is somewhat less puckered than in the $\mathrm{W}_{2} \mathrm{Fe}$ cluster, with a $\mathrm{P}-\mathrm{W} 1-\mathrm{W} 2-\mathrm{W} 3$ angle of ca. $167^{\circ}$, and the terminal nitrosyls display the usual distinct orientation relative to the intermetallic bond $\left(\mathrm{N}-\mathrm{W}-\mathrm{W}\right.$ angles ca. 84 and $\left.111^{\circ}\right)$. 


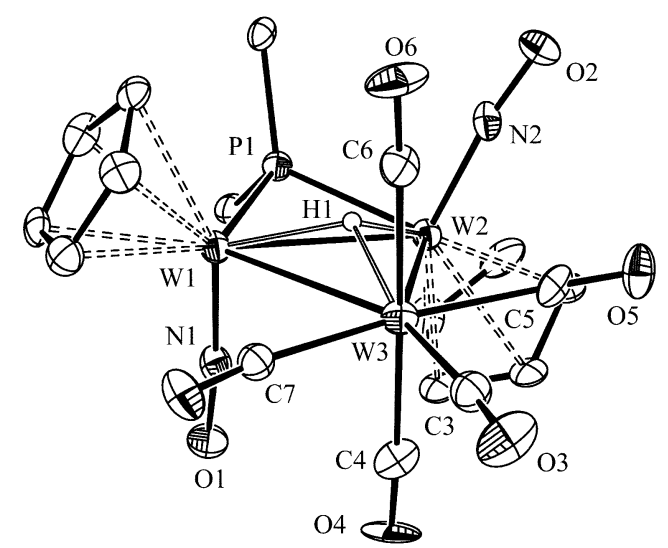

Figure 2. ORTEP diagram (30\% probability) of compound 3, with $\mathrm{H}$ atoms (except the hydride ligand) and $\mathrm{Ph}$ rings (except their $\mathrm{C}^{1}$ atoms) omitted for clarity.

Table 2. Selected bond lengths $(\AA)$ and angles $\left({ }^{\circ}\right)$ for compound $\mathbf{3}$

\begin{tabular}{llll}
\hline W1-W2 & $3.006(1)$ & W1-P1-W2 & $77.0(1)$ \\
W1-W3 & $3.164(1)$ & W1-W3-W2 & $56.87(2)$ \\
W2-W3 & $3.150(1)$ & P1-W1-N1 & $91.8(4)$ \\
W1-P1 & $2.401(4)$ & P1-W2-N2 & $98.9(4)$ \\
W2-P1 & $2.429(4)$ & N1-W1-W2 & $84.2(4)$ \\
W1-N1 & $1.78(1)$ & N2-W2-W1 & $110.9(4)$ \\
W2-N2 & $1.79(1)$ & P1-W1-H1 & $81.4(6)$ \\
W3-C3 & $1.99(2)$ & P1-W2-H1 & $80.7(6)$ \\
W3-C4 & $2.08(2)$ & H1-W3-C3 & $165(1)$ \\
W3-C5 & $2.06(2)$ & C4-W3-C6 & $176.7(6)$ \\
W3-C6 & $2.06(2)$ & C5-W3-C7 & $166.1(6)$ \\
W3-C7 & $2.06(2)$ & C3-W3-C4 & $90.4(7)$ \\
W1-H1 & $1.90(2)$ & C3-W3-C6 & $92.9(7)$ \\
W2-H1 & $1.90(2)$ & C3-W3-C5 & $82.7(6)$ \\
W3-H1 & $1.90(2)$ & C3-W3-C7 & $83.6(6)$ \\
\hline
\end{tabular}

The molecule of $\mathbf{3}$ can be viewed as an acid-base adduct resulting from the interaction of the LUMO of the $\mathrm{W}(\mathrm{CO})_{5}$ fragment with the filled molecular orbital which describes the tricentric $\mathrm{W}_{2} \mathrm{H}$ interaction of the unsaturated hydride $\mathbf{1}^{7}$ a behaviour previously observed as well in the addition of the $\mathrm{W}(\mathrm{CO})_{5}$ fragment to the 32-electron dihydride $\left[\mathrm{Mn}_{2}(\mu-\mathrm{H})_{2}(\mathrm{CO})_{6}\left\{\mu-(\mathrm{EtO})_{2} \mathrm{POP}(\mathrm{OEt})_{2}\right\}\right],{ }^{4 \mathrm{a}}$ and also in the case of the 30-electron hydrides $\left[\mathrm{M}_{2} \mathrm{Cp}_{2}(\mu-\mathrm{H})\left(\mu-\mathrm{PCy}_{2}\right)(\mathrm{CO})_{2}\right]\left(\mathrm{M}=\mathrm{Mo}^{24} \mathrm{~W}\right){ }^{25}$ Therefore we could say that the added $\mathrm{W}(\mathrm{CO})_{5}$ fragment is behaving in a $\mathrm{H}^{+}$-like way in this reaction, and it would formally provide with no further electrons to the unsaturated $\mathrm{W}_{2}(\mathrm{NO})_{2}$ moiety of the parent precursor $\mathbf{1}$, which then should remain unsaturated to some extent, even if $\mathbf{3}$ should be classified itself as an electron-precise trinuclear cluster (48 valence electrons). This is consistent with the W1-W2 length of 3.006(1) $\AA$, which is ca. $0.04 \AA$ shorter than the corresponding distance in the iron cluster 2 , although certainly much longer than the intermetallic separation at the parent compound $\mathbf{1}(2.7699 \text { (7) A })^{7}$ 
Table 3. Selected IR, ${ }^{a}$ and ${ }^{31} \mathrm{P}\left\{{ }^{1} \mathrm{H}\right\}$ data ${ }^{b}$ for new compounds.

\begin{tabular}{|c|c|c|c|}
\hline Compound & $v(\mathrm{CO})$ & $v(\mathrm{NO})$ & $\delta(\mathrm{P})\left[J_{\mathrm{PW}}\right]$ \\
\hline$\left[\mathrm{W}_{2} \mathrm{Cp}_{2}(\mu-\mathrm{H})\left(\mu-\mathrm{PPh}_{2}\right)(\mathrm{NO})_{2}\right](\mathbf{1})^{c}$ & & 1580 (w, sh), 1552 (vs) & $212.8[375]$ \\
\hline$\left[\mathrm{FeW}_{2} \mathrm{Cp}_{2}(\mu-\mathrm{H})\left(\mu-\mathrm{PPh}_{2}\right)(\mathrm{CO})_{4}(\mathrm{NO})_{2}\right](\mathbf{2})$ & $\begin{array}{l}2056(\mathrm{vs}), 2001(\mathrm{~s}) \\
1986(\mathrm{~s}), 1968(\mathrm{~m})^{d}\end{array}$ & $1611(\mathrm{~m}, \mathrm{sh}), 1598(\mathrm{vs})^{d}$ & $161.3[310]$ \\
\hline$\left[\mathrm{W}_{3} \mathrm{Cp}_{2}\left(\mu_{3}-\mathrm{H}\right)\left(\mu-\mathrm{PPh}_{2}\right)(\mathrm{CO})_{5}(\mathrm{NO})_{2}\right](\mathbf{3})$ & $\begin{array}{l}2056(\mathrm{~s}), 1965(\mathrm{~m}, \mathrm{sh}) \\
1949(\mathrm{vs}), 1926(\mathrm{~s})\end{array}$ & 1606 (w, sh), 1588 (m) & $143.5[320]$ \\
\hline$\left[\mathrm{MoW}_{2} \mathrm{Cp}_{2}\left(\mu_{3}-\mathrm{H}\right)\left(\mu-\mathrm{PPh}_{2}\right)(\mathrm{CO})_{5}(\mathrm{NO})_{2}\right]$ (4) & $2058(\mathrm{~m})^{e}$ & & $149.7[325]$ \\
\hline$\left[\mathrm{MnW}_{2} \mathrm{Cp}_{2} \mathrm{Cp}^{\prime}\left(\mu_{3}-\mathrm{H}\right)\left(\mu-\mathrm{PPh}_{2}\right)(\mathrm{CO})_{2}(\mathrm{NO})_{2}\right](\mathbf{5})$ & 1916 (vs), $1861(\mathrm{~m})$ & $1588(\mathrm{~m}, \mathrm{sh}), 1560(\mathrm{~s})$ & $138.6[342,318]$ \\
\hline$\left[\mathrm{CoWCp}\left(\mu-\mathrm{PPh}_{2}\right)(\mathrm{CO})_{4}(\mathrm{NO})\right](6)^{e}$ & $\begin{array}{l}2036 \text { (vs), } 1974 \text { (vs), } \\
1965 \text { (vs), } 1928(\mathrm{w}, \mathrm{sh})\end{array}$ & $1643(\mathrm{~m})$ & $195.3[408]$ \\
\hline$\left[\mathrm{CoW}_{2} \mathrm{Cp}_{2}\left(\mu-\mathrm{PPh}_{2}\right)(\mathrm{CO})_{4}(\mathrm{NO})_{2}\right](7)$ & $\begin{array}{l}2037(\mathrm{vs}), 1987(\mathrm{~m}), \\
1838(\mathrm{w}), 1795(\mathrm{w})\end{array}$ & $1608(\mathrm{~s})$ & $163.4[288]$ \\
\hline
\end{tabular}

${ }^{a}$ Recorded in dichloromethane solution, with $\mathrm{X}-\mathrm{O}$ stretching bands $[v(\mathrm{XO})]$ in $\mathrm{cm}^{-1}(\mathrm{X}=\mathrm{C}, \mathrm{N}){ }^{b}$ Recorded in $\mathrm{CD}_{2} \mathrm{Cl}_{2}$ solution at $121.49 \mathrm{MHz}$ and $293 \mathrm{~K}$ unless otherwise stated, with chemical shifts $(\delta)$ in ppm and ${ }^{31} \mathrm{P}_{-}{ }^{183} \mathrm{~W}$ couplings $\left(J_{\mathrm{PW}}\right)$ in $\mathrm{Hz} .{ }^{c}$ Data taken from reference $7 .{ }^{d}$ In petroleum ether solution. ${ }^{e}$ Other bands obscured by the intense bands of $\left[\mathrm{Mo}(\mathrm{CO})_{6}\right]$ and $\left[\mathrm{W}_{2} \mathrm{Cp}_{2} \mathrm{H}\left(\mu-\mathrm{PPh}_{2}\right)(\mathrm{CO})(\mathrm{NO})_{2}\right]$ present in the reaction mixture (see text).

\section{Solution structure and dynamics of the hydride cluster 2}

Spectroscopic data in solution for 2 (Table 3 and Experimental Section) are essentially consistent with the structure found in the crystal, but indicate dynamic behaviour in solution. In the first place, the IR spectrum of this compound in petroleum ether expectedly displays four $\mathrm{C}-\mathrm{O}$ stretches and two $\mathrm{N}-\mathrm{O}$ stretches, the latter with the relative intensity (weak and strong, in order of decreasing frequency) corresponding to a transoid $\mathrm{W}_{2}(\mathrm{NO})_{2}$ oscillator. ${ }^{26,27}$ The relative intensities of the carbonyl stretches, however, are not as expected for a $\mathrm{M}(\mathrm{CO})_{4}$ oscillator with local $C_{2 \mathrm{v}}$ symmetry, for which the symmetric stretch (the most energetic band) is expected to give a band of medium intensity. However, the most energetic $\mathrm{C}-\mathrm{O}$ stretch in $\mathbf{2}$ displays the strongest intensity, which rather is a characteristic of pyramidal $\mathrm{M}(\mathrm{CO})_{3}$ fragments under any local symmetry. ${ }^{27}$ A closer inspection of the carbonyls in the crystal structure of 2 reveals that the $\mathrm{C} 3-\mathrm{O} 3$ ligand departs slightly from linearity $\left(\mathrm{Fe}-\mathrm{C}-\mathrm{O} 172(2)^{\circ}\right)$, with a very incipient bending towards a $\mu_{3}$-coordination over the $\mathrm{W}_{2} \mathrm{Fe}$ triangle $(\mathrm{C} 3 \cdots \mathrm{W}$ ca. $3.0 \AA$ ). We wondered whether such a distortion would remain in solution, since this could account for the anomalous intensities of the $\mathrm{C}-\mathrm{O}$ stretching bands. To answer this question, we optimized the gas-phase structure of 2 using DFT methods (see the Experimental Section and Electronic Supplementary Information -ESI-). Actually we found that, in addition to the structure found in the crystal, two other isomers were genuine minima in the corresponding potential energy surface, one with the hydride bridging the other $\mathrm{W}-\mathrm{Fe}$ edge (2') and one with the hydride bridging over the $\mathrm{W}_{2} \mathrm{Fe}$ face (2F) (Figure 3), these having a Gibbs free energy only 3 and $5 \mathrm{~kJ} / \mathrm{mol}$ higher than 2 , respectively. 

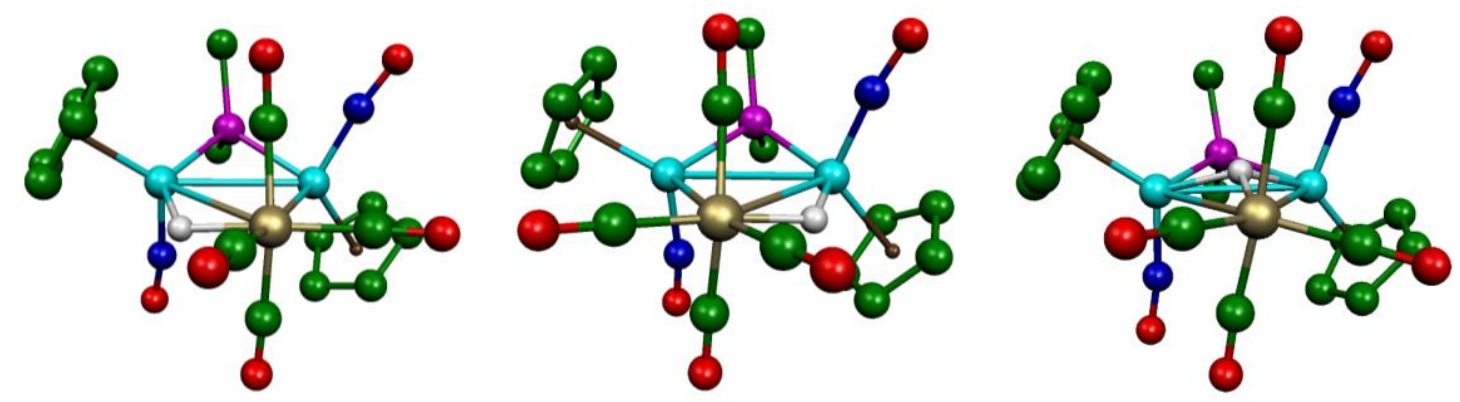

Figure 3. B3LYP DFT-optimized structures of compound 2 (left) and the isomers 2' (centre) and $\mathbf{2 F}$ (right), with most $\mathrm{H}$ atoms and $\mathrm{Ph}$ groups (except their $\mathrm{C}^{1}$ atoms) omitted for clarity and labelling as shown in Figure 1. Relative Gibbs free energies were $0,+3$ and $+5 \mathrm{~kJ} / \mathrm{mol}$ respectively. Selected bond lengths $(\AA)$ for 2 : $\mathrm{W} 1-\mathrm{W} 2=3.116 ; \mathrm{W} 1-\mathrm{Fe}=3.003 ; \mathrm{W} 2-\mathrm{Fe}=2.786 ; \mathrm{W} 1-\mathrm{H}=1.811 ; \mathrm{Fe}-\mathrm{H}=1.684$. Isomer 2': $\mathrm{W} 1-\mathrm{W} 2=3.112 ; \mathrm{W} 1-\mathrm{Fe}=2.791 ; \mathrm{W} 2-\mathrm{Fe}=3.057 ; \mathrm{W} 2-\mathrm{H}=1.796 ; \mathrm{Fe}-\mathrm{H}=1.680$. Isomer 2F: $\mathrm{W} 1-\mathrm{W} 2=3.060 ; \mathrm{W} 1-\mathrm{Fe}=2.991 ; \mathrm{W} 2-\mathrm{Fe}=2.981 ; \mathrm{W} 1-\mathrm{H}=1.820 ; \mathrm{W} 2-\mathrm{H}=1.874 ; \mathrm{Fe}-\mathrm{H}=1.721$.

First we note that the DFT-optimized structure for $\mathbf{2}$ is in good agreement with the one determined in the crystal, although the computed distances involving the metal atoms are somewhat overestimated in general, as commonly found in this type of calculations. ${ }^{28}$ Interestingly, the slight bending found in the solid state for one the carbonyls is reproduced in the gas-phase structure $\left(\mathrm{Fe}-\mathrm{C}-\mathrm{O}\right.$ ca. $169^{\circ}, \mathrm{C} \cdots \mathrm{W}$ ca. 2.92 and $3.07 \AA$ ), and in fact the computed $\mathrm{C}-\mathrm{O}$ stretches for 2 satisfactorily fit to the experimental spectrum after allowing for the ca. $5 \%$ frequency overestimation usual in these calculations, ${ }^{29}$ with the symmetric stretch indeed displaying the highest intensity (see the ESI). A similar structural distortion and comparable $\mathrm{C}-\mathrm{O}$ stretches were computed for isomer 2', but the presence of the latter in solution can be safely discarded on the basis of the predicted $\mathrm{N}-\mathrm{O}$ vibrations, which are mixed with the $\mathrm{W}-\mathrm{H}$ vibration and thus would render two $\mathrm{N}-\mathrm{O}$ stretches of similar intensity (see the ESI), then strongly departing from the experimental intensities (Table 3). As for isomer 2F, we note that it displays a shorter $\mathrm{W}-\mathrm{W}$ separation as anticipated $\left(\mathrm{CH}_{2^{-}}\right.$vs. $\mathrm{H}^{+}$-like behaviour), and an essentially undistorted $\mathrm{Fe}(\mathrm{CO})_{4}$ fragment. As a result of the latter, the computed $\mathrm{C}-\mathrm{O}$ stretches expectedly yields a symmetric stretch of weaker intensity than the ones computed for isomers $\mathbf{2}$ and 2', therefore the presence in solution of significant amounts of this isomer can be safely discarded too.

The NMR data for $\mathbf{2}$ at room temperature, however, are indicative of chemical equivalence of the tungsten atoms, apparently related by a $C_{2}$ operation, which is not consistent with the static structure of the molecule. This is indicated by the appearance of single ${ }^{1} \mathrm{H}$ and ${ }^{13} \mathrm{C}$ NMR cyclopentadienyl resonances, a single set of ${ }^{13} \mathrm{C}$ phenyl resonances, and by the identical coupling to both ${ }^{183} \mathrm{~W}$ nuclei of the $\mathrm{P}$ atom $\left(\delta_{\mathrm{P}} 161.3\right.$ ppm, $\left.J_{\mathrm{PW}}=310 \mathrm{~Hz}\right)$ and of the hydride ligand $\left(\delta_{\mathrm{H}}-11.95 \mathrm{ppm}, J_{\mathrm{HW}}=32 \mathrm{~Hz}\right)$, which obviously are time-averaged values. Unfortunately, no significant changes in the above spectra were observed upon lowering the temperature down to ca. $183 \mathrm{~K}$, except for a broadening of the averaged ${ }^{13} \mathrm{C}$ NMR carbonyl resonance of the $\mathrm{Fe}(\mathrm{CO})_{4}$ fragment, 
clearly involved in an independent carbonyl exchange process. As concerning the dynamic process involving the ditungsten centre, we note that the averaged $\mathrm{W}-\mathrm{H}$ coupling of $32 \mathrm{~Hz}$ is much lower than a conventional W-H-Fe coupling (cf. $53 \mathrm{~Hz}$ in the cluster $\left.\left[\mathrm{Fe}_{2} \mathrm{~W}_{2} \mathrm{Cp}_{2}(\mu-\mathrm{H})\left(\mu-\mathrm{PCy}_{2}\right)(\mathrm{CO})_{8}\right]\right),{ }^{25}$ and may result from a dynamic process where the hydride ligand moves from one $\mathrm{W}-\mathrm{Fe}$ edge to the other one. ${ }^{30}$ For such a process we propose the rearrangements depicted in Scheme 2. These would involve the change of the hydride ligand from $\mu_{2}$ to $\mu_{3}$ - and then back to the $\mu_{2}$-coordination mode ( $\mathbf{2} \rightarrow \mathbf{2 F} \rightarrow \mathbf{2}$ ' interconversions), which are assumed to be kinetically very accessible because the heavy-atom skeleton of the molecule is not greatly disturbed along the way. This should be coupled to a flapping movement of the central $\mathrm{PW}_{2} \mathrm{Fe}$ skeleton at isomer $\mathbf{2 F}$, which is needed to generate the apparent $C_{2}$ axis relating the $\mathrm{WCp}(\mathrm{NO})$ fragments of the cluster in the time-averaged spectra. The latter movement involves a larger geometrical distortion in the molecule, and should define the overall barrier of the dynamic process, but still should be readily accessible since it is comparable to the rearrangement operating at the structurally related dicarbonyl complexes $\left[\mathrm{M}_{2} \mathrm{Cp}_{2}(\mu-\right.$ $\left.\left.\mathrm{PCy}_{2}\right)\left(\mu-\mathrm{SnPh}_{3}\right)(\mathrm{CO})_{2}\right]$ mentioned above, which also remained fluxional at low temperatures. $^{13,14}$

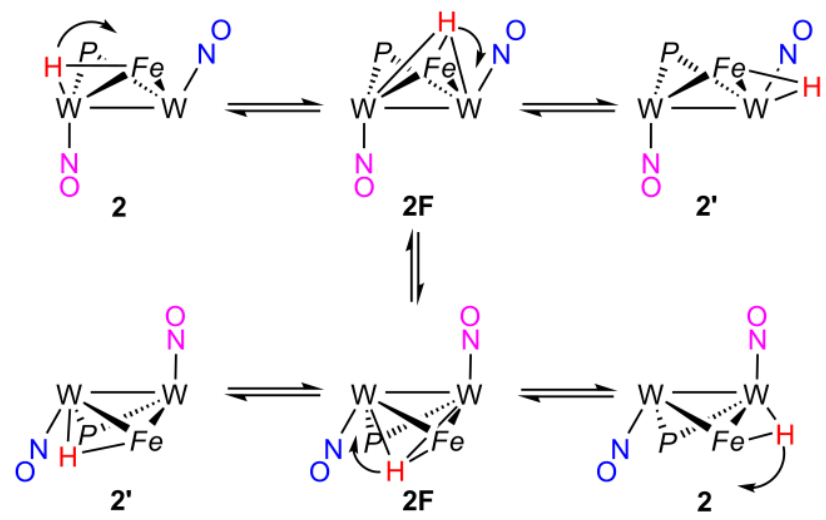

Scheme 2. Dynamic process proposed for cluster 2 (schematic view, with $\mathrm{Cp}$ ligands omitted; $\mathrm{Fe}=$ $\left.\mathrm{Fe}(\mathrm{CO})_{4} ; P=\mathrm{PPh}_{2}\right)$.

\section{Solution structure and dynamics of hydride clusters 3 to 5}

The IR spectra of these clusters display in all cases $\mathrm{N}-\mathrm{O}$ stretches comparable to those of 2 , indicative of the retention of transoid $\mathrm{W}_{2}(\mathrm{NO})_{2}$ oscillators in these molecules. In addition, cluster 5 displays two $\mathrm{C}-\mathrm{O}$ stretches characteristic of [ $\left.\mathrm{MnCp}^{\prime}(\mathrm{CO})_{2} \mathrm{~L}\right]$ complexes, while the tritungsten cluster 3 displays four $\mathrm{C}-\mathrm{O}$ stretches between ca. 2060 and $1930 \mathrm{~cm}^{-1}$ with the pattern characteristic of octahedral $\left[\mathrm{M}(\mathrm{CO})_{5} \mathrm{~L}\right]$ complexes. $^{27}$ The $\mathrm{C}-\mathrm{O}$ stretches of the $\mathrm{W}_{2}$ Mo cluster 4 could not be fully identified in the spectra of the crude reaction mixtures, due to the presence of other strong bands in the same region, but the observation of a medium-intensity band at $2058 \mathrm{~cm}^{-1}$ denotes the presence of a $\mathrm{Mo}(\mathrm{CO})_{5}$ fragment in this molecule. 
The phosphanyl ligands in clusters 3 to 5 display ${ }^{31} \mathrm{P}$ chemical shifts around 140 ppm, some 20 ppm below the iron cluster 2, with comparable P-W couplings of 320$340 \mathrm{~Hz}$. The manganese cluster 5 exhibits similar but distinct couplings of 342 and 318 $\mathrm{Hz}$ to the inequivalent $\mathrm{W}$ atoms as expected, but the pentacarbonyl clusters $\mathbf{3}$ and $\mathbf{4}$ display in each case identical $\mathrm{P}$ couplings of ca. $320 \mathrm{~Hz}$ to both ${ }^{183} \mathrm{~W}$ nuclei, again denoting dynamic behaviour in these cases. Other spectroscopic data for $\mathbf{5}$ are in agreement with the lack of symmetry for this cluster, which implies the observation of two $\mathrm{Cp}$ and carbonyl resonances, or five ${ }^{1} \mathrm{H}$ and six ${ }^{13} \mathrm{C}$ NMR resonances for the $\mathrm{C}_{5} \mathrm{H}_{4} \mathrm{Me}$ ligand bound to the manganese atom. The hydride ligand gives rise to a ${ }^{1} \mathrm{H}$ NMR resonance at $-7.67 \mathrm{ppm}$ showing identical couplings of $80 \mathrm{~Hz}$ to both ${ }^{183} \mathrm{~W}$ nuclei, which we interpret as an accidental degeneracy. We finally note that two different conformers of $\mathbf{5}$ might be consistent with all the above data, these differing in the relative orientation of the Cp' and $\mathrm{PPh}_{2}$ ligands with respect to the $\mathrm{W}_{2} \mathrm{Mn}$ plane. The conformation depicted for 5 in Scheme 1 (Cp' and $\mathrm{PPh}_{2}$ ligands on the same side of the metal plane) is based on the solid-state structure of the related carbonyl cluster $\left[\mathrm{MnMo}_{2} \mathrm{Cp}_{2} \mathrm{Cp}{ }^{\prime}\left(\mu_{3}-\mathrm{H}\right)\left(\mu-\mathrm{PCy}_{2}\right)(\mathrm{CO})_{4}\right]{ }^{24}$ and presumably would be the one better minimizing the steric repulsions among the different ligands surrounding the trimetal core of the cluster.

Further indications of dynamic effects in the tritungsten cluster 3 are the observation of single ${ }^{1} \mathrm{H}$ and ${ }^{13} \mathrm{C}$ NMR cyclopentadienyl resonances, a single set of ${ }^{13} \mathrm{C}$ phenyl resonances, and the identical coupling of the hydride ligand $\left(\delta_{\mathrm{H}}-5.69 \mathrm{ppm}\right)$ to two ${ }^{183} \mathrm{~W}$ nuclei $(74 \mathrm{~Hz})$. The latter also displays a coupling of $40 \mathrm{~Hz}$ to a third ${ }^{183} \mathrm{~W}$ nucleus, obviously the one belonging to the $\mathrm{W}(\mathrm{CO})_{5}$ fragment (cf. $36 \mathrm{~Hz}$ in the related carbonyl cluster $\left.\left.\left[\mathrm{WMo}_{2} \mathrm{Cp}_{2}\left(\mu_{3}-\mathrm{H}\right)(\mu-\mathrm{PCy})_{2}\right)(\mathrm{CO})_{7}\right]\right) .{ }^{24}$ Once again, these spectroscopic data are indicative of the occurrence of a dynamic process relating the inequivalent $\mathrm{WCp}(\mathrm{NO})$ fragments and phenyl rings through an apparent $C_{2}$ symmetry element. Upon cooling the solution, the NMR spectra of 3 remained essentially unchanged down to ca. $173 \mathrm{~K}$; however, at the latter temperature a significant broadening of the outer satellite lines of the hydride resonance was observed, not present in the inner satellite lines (which are due to coupling to the $\mathrm{W}(\mathrm{CO})_{5}$ fragment). This is taken as an experimental evidence of incipient transition of the spectrum into the slow-exchange regime, where two distinct couplings to the nitrosyl-bound $\mathrm{W}$ atoms should be observed. To account for the observed averaging of resonances we propose for $\mathbf{3}$ a flapping motion of the heavy-atom skeleton comparable to the one proposed for the isomer $\mathbf{2} \mathbf{F}$ of the iron cluster $\mathbf{2}$ (Scheme 3). 


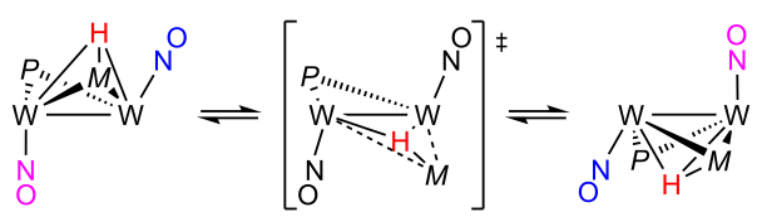

Scheme 3. Fluxional process proposed for cluster $\mathbf{3}$ (schematic view, with $\mathrm{Cp}$ ligands omitted; $M=$ $\left.\mathrm{W}(\mathrm{CO})_{5} ; P=\mathrm{PPh}_{2}\right)$.

The above fluxional process is completely analogous to the one proposed to account for the dynamic behaviour of the mentioned carbonyl cluster $\left[\mathrm{WMo}_{2} \mathrm{Cp}_{2}\left(\mu_{3}-\mathrm{H}\right)(\mu-\right.$ $\left.\left.\left.\mathrm{PCy}_{2}\right)(\mathrm{CO})_{7}\right]\right) .{ }^{24}$ However, when analyzing the variable-temperature NMR spectra of the related tritungsten cluster $\left[\mathrm{W}_{3} \mathrm{Cp}_{2}\left(\mu_{3}-\mathrm{H}\right)\left(\mu-\mathrm{PCy}_{2}\right)(\mathrm{CO})_{7}\right]$ we detected at very low temperatures the presence of a second isomer, presumably having an edge-bridging hydride ligand and involved in the overall dynamic process. ${ }^{25}$ In order to examine the role of edge-bridged structures in the dynamics of $\mathbf{3}$ we have searched for alternative isomers of the latter cluster by using DFT methods, and indeed we have found that two edge-bridged isomers (3E and $\mathbf{3 E ^ { \prime }}$ ) are genuine minima in the corresponding potential energy surface (Figure 4 and ESI). These are comparable to the isomers 2 and 2', computed for the iron cluster, and expectedly display W1-W2 lengths significantly longer than 3 by ca. $0.14 \AA\left(\mathrm{CH}_{2}\right.$-like behaviour of the $\mathrm{W}(\mathrm{CO})_{5}$ fragment). The significant difference here, however, is that the edge-bridged isomers now are much less stable than the face-bridged 3, with their Gibbs free energies actually being 37 and 51 $\mathrm{kJ} / \mathrm{mol}$ higher, respectively. This might be related to the higher steric demands of the $\mathrm{M}(\mathrm{CO})_{5}$ fragment (compared to a $\mathrm{M}(\mathrm{CO})_{4}$ one), as judged from the fact that, in the edge-bridged isomers, one of the equatorial carbonyls is forced into close contact with the other $\mathrm{WCp}(\mathrm{NO})$ fragment, it actually becoming an asymmetrically bridging group (W-CO distances ca. 2.12 and $2.35 \AA$ ) departing from the ideal octahedral-derived arrangement of carbonyls at the $\mathrm{W}(\mathrm{CO})_{5}$ fragment. In any case, due to their relatively high energetic content, it is very unlikely that isomers $\mathbf{3 E}$ and $\mathbf{3 E}$ ' could play a significant role in the dynamics of $\mathbf{3}$ in solution at room temperature or below. The largest energetic cost of the fluxional process depicted in Scheme 3 likely arises from the geometrical rearrangement of the heavy atoms, which is similar to the one taking place in the related and highly fluxional dicarbonyl complexes $\left[\mathrm{M}_{2} \mathrm{Cp}_{2}\left(\mu-\mathrm{PCy}_{2}\right)(\mu-\right.$ $\left.\mathrm{SnPh}_{3}\right)(\mathrm{CO})_{2}$ ], ${ }^{13,14}$ as noted above. In the case of $\mathbf{3}$ (and also of isomer $\mathbf{2 F}$ ), this rearrangement would proceed through a transition state displaying a planar $\mathrm{PW}{ }_{2} \mathrm{Fe}\left(\mu_{3}\right.$ $\mathrm{H})$ core with weakened intermetallic interactions. From the point of view of the hydride ligand, the process might be described as a sort of pyramidal inversion going through a trigonal transition state. Although we are not aware of previous estimations on the energetic cost of this rearrangement, we note its similitude with the fluxionality of $\mu_{2}-\mathrm{H}$ ligands in binuclear complexes via linear $\mathrm{M}-\mathrm{H}-\mathrm{M}$ transition states, which has been 
computed to have activation barriers as low as $18 \mathrm{~kJ} / \mathrm{mol}$ in the absence of additional bond-breaking processes. $^{31}$
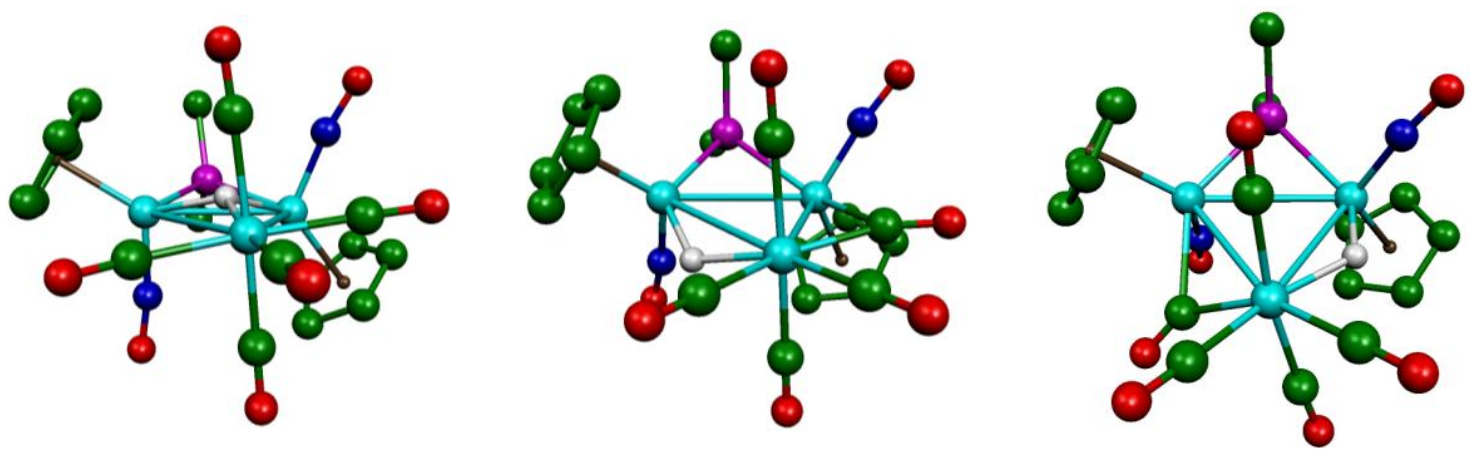

Figure 4. B3LYP DFT-optimized structures of compound $\mathbf{3}$ (left) and the isomers $\mathbf{3 E}$ (centre) and $\mathbf{3 \mathbf { E } ^ { \prime }}$ (right), with most $\mathrm{H}$ atoms and $\mathrm{Ph}$ groups (except their $\mathrm{C}^{1}$ atoms) omitted for clarity and labelling as shown in Figure 2. Relative Gibbs free energies were $0,+37$ and $+51 \mathrm{~kJ} / \mathrm{mol}$ respectively. Selected bond lengths $(\AA)$ for 3: $\mathrm{W} 1-\mathrm{W} 2=3.050 ; \mathrm{W} 1-\mathrm{W} 3=3.340 ; \mathrm{W} 2-\mathrm{W} 3=3.294 ; \mathrm{W} 1-\mathrm{H}=1.851 ; \mathrm{W} 2-\mathrm{H}=1.900$; $\mathrm{W} 3-\mathrm{H}=1.981$. Isomer 3E: $\mathrm{W} 1-\mathrm{W} 2=3.190 ; \mathrm{W} 1-\mathrm{W} 3=3.270 ; \mathrm{W} 2-\mathrm{W} 3=3.132 ; \mathrm{W} 1-\mathrm{H}=1.777 ; \mathrm{W} 3-\mathrm{H}$ $=1.883$. Isomer 3E': W1-W2 = 3.234; W1-W3 = 3.179; W2-W3 = 3.267; W2-H = 1.775; W3-H = 1.885 .

\section{Reactions of 1 with metal carbonyl dimers}

Previous work on the 30-electron hydride $\left[\mathrm{Mo}_{2} \mathrm{Cp}_{2}(\mu-\mathrm{H})\left(\mu-\mathrm{PCy}_{2}\right)(\mathrm{CO})_{2}\right]$ revealed its ability to react with metal carbonyl dimers $\mathrm{M}_{2} \mathrm{~L}_{2 \mathrm{n}}$ via a radical pathway resulting in formal replacement of the bridging $\mathrm{H}$ atom with 17-electron $\mathrm{ML}_{\mathrm{n}}$ fragments $\left(\mathrm{ML}_{\mathrm{n}}=\right.$ $\left.\mathrm{MCp}(\mathrm{CO})_{3}, \mathrm{Mn}(\mathrm{CO})_{5}\right)$ to render heterometallic $\mathrm{Mo}_{2} \mathrm{M}$ clusters. ${ }^{24} \mathrm{We}$ have explored this synthetic strategy in the case of the unsaturated hydride $\mathbf{1}$ by reacting it with several carbonyl dimers such as $\left[\mathrm{M}_{2} \mathrm{Cp}_{2}(\mathrm{CO})_{6}\right](\mathrm{M}=\mathrm{Mo}, \mathrm{W})$ and $\left[\mathrm{M}_{2}(\mathrm{CO})_{10}\right](\mathrm{M}=\mathrm{Mn}, \mathrm{Re})$ under either visible (Mo, W) or UV irradiation (Mo, W, Mn, Re). In all cases, complex mixtures were obtained, with the major products being identified as the known binuclear complexes $\left[\mathrm{W}_{2} \mathrm{Cp}_{2} \mathrm{H}\left(\mu-\mathrm{PPh}_{2}\right)(\mathrm{CO})(\mathrm{NO})_{2}\right]$ (the carbonylation product of $\mathbf{1}$ ) and $\left[\mathrm{W}_{2} \mathrm{Cp}_{2}\left(\mu-\mathrm{PPh}_{2}\right)_{2}(\mathrm{NO})_{2}\right]^{32}$ (Scheme 4). In contrast, 1 reacted with $\left[\mathrm{Co}_{2}(\mathrm{CO})_{8}\right]$ at $253 \mathrm{~K}$ in the dark to give a mixture of the binuclear complex $\left[\mathrm{CoWCp}\left(\mu-\mathrm{PPh}_{2}\right)(\mathrm{CO})_{4}(\mathrm{NO})\right](6)$ and the sought trinuclear cluster $\left[\mathrm{CoW}_{2} \mathrm{Cp}_{2}\left(\mu-\mathrm{PPh}_{2}\right)(\mathrm{CO})_{4}(\mathrm{NO})_{2}\right](7)$ as major products, which could be respectively isolated in 20 and 30\% yields after chromatographic workup. The formation of 7 expectedly follows from a formal replacement of the hydride ligand in 1 with the 17-electron fragment $\mathrm{Co}(\mathrm{CO})_{4}$. The latter species in turn would be formed easily in solution upon homolytic dissociation of $\left[\mathrm{Co}_{2}(\mathrm{CO})_{8}\right]$, and likely would also act as hydrogen trap by forming the corresponding mononuclear hydride $\left[\mathrm{CoH}(\mathrm{CO})_{4}\right]$, although this was not investigated. In contrast, the formation of 6 is unexpected, and likely follows from cluster degradation of the paramagnetic intermediate $\left[\mathrm{CoW}_{2} \mathrm{Cp}_{2}\left(\mu_{3}-\mathrm{H}\right)\left(\mu-\mathrm{PPh}_{2}\right)(\mathrm{CO})_{4}(\mathrm{NO})_{2}\right]$ that would be formed upon initial reaction of the radical $\mathrm{Co}(\mathrm{CO})_{4}$ with $\mathbf{1}$, which likely proceeds to the formation of $\mathbf{7}^{24}$ 


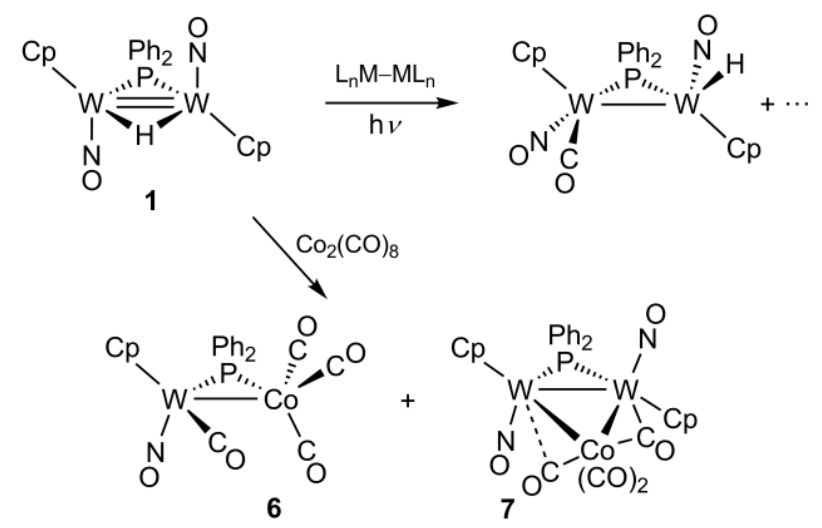

Scheme 4. Reactions of hydride 1 with metal carbonyl dimers $\left(\mathrm{ML}_{\mathrm{n}}=\mathrm{MoCp}(\mathrm{CO})_{3}, \mathrm{WCp}(\mathrm{CO})_{3}\right.$, $\left.\mathrm{Mn}(\mathrm{CO})_{5}, \operatorname{Re}(\mathrm{CO})_{5}\right)$.

\section{Structure of the WCo complex 6}

The molecule of 6 in the crystal (Figure 5 and Table 4) is built from $\mathrm{WCp}(\mathrm{NO})(\mathrm{CO})$ and $\mathrm{Co}(\mathrm{CO})_{3}$ fragments connected by a diphenylphosphanyl bridge, with the W-bound carbonyl leaning over the intermetallic vector in a very incipient semibridging interaction with the Co atom (W-C-O ca. $170^{\circ}, \mathrm{C} \cdots$ Co ca. $2.68 \AA$ ), and trans to the $\mathrm{P}$ atom $\left(\mathrm{P}-\mathrm{W}-\mathrm{C}\right.$ ca. $\left.111^{\circ}\right)$, much in the same way as recently determined for the homonuclear nitrosyl complex $\left[\mathrm{Mo}_{2} \mathrm{Cp}_{2}\left(\mu-\mathrm{PPh}_{2}\right)(\mathrm{CO})_{3}(\mathrm{NO})\right] \cdot{ }^{33}$ In order to achieve a 18 electron configuration at each metal centre, an asymmetric coordination of the phosphanyl ligand ( $\mathrm{W}-\mathrm{PR}_{2} \rightarrow \mathrm{Co}$ ) might be proposed for $\mathbf{6}$, which should be reflected in the observation of a shorter $\mathrm{P}-\mathrm{Co}$ length, even after allowing for the lower size of the Co atom. However, the $\mathrm{W}-\mathrm{P}$ and $\mathrm{Co}-\mathrm{P}$ lengths only differ from each other by some $0.22 \AA$, while the covalent radii of these metal atoms differ by some $0.35 \AA$. This indicates that the coordination of the phosphanyl ligand in $\mathbf{6}$ to the $\mathrm{W}$ atom is stronger than anticipated, perhaps counterbalanced by the mentioned semibridging coordination of the W-bound carbonyl. In any case, the molecule can be classified as a 34-electron complex for which a intermetallic single bond should be proposed, in agreement with the corresponding length of 2.8623(6) $\AA$, almost perfectly matching the expected value of $2.88 \AA$ for a W-Co single bond. ${ }^{34} \mathrm{~A}$ search at the Cambridge crystallographic database, however, revealed that P-bridged $\mathrm{M}-\mathrm{Co}$ single bonds $(\mathrm{M}=\mathrm{Mo}, \mathrm{W})$ span a quite wide range of intermetallic distances (ca. 2.57-3.00 $\AA$ ) depending on other geometrical variables, particularly the number and nature of additional bridging ligands. We finally note that the overall structure of this molecule is comparable to that of the isoelectronic phosphinidene-bridged complex $\left[\mathrm{CoMoCp}(\mu-\mathrm{PR} *)(\mathrm{CO})_{5}\right]\left(\mathrm{R}^{*}=2,4,6-\right.$ $\mathrm{C}_{6} \mathrm{H}_{2}{ }^{t} \mathrm{Bu}_{3}$ ), although the $\mathrm{M}-\mathrm{P}$ distances here were some $0.11 \AA$ shorter (due to the multiplicity of the corresponding M-P bonds) and the intermetallic separation $0.11 \AA$ longer (due to the spatial demands of the bulky $\mathrm{R}^{*}$ group). ${ }^{35}$ 


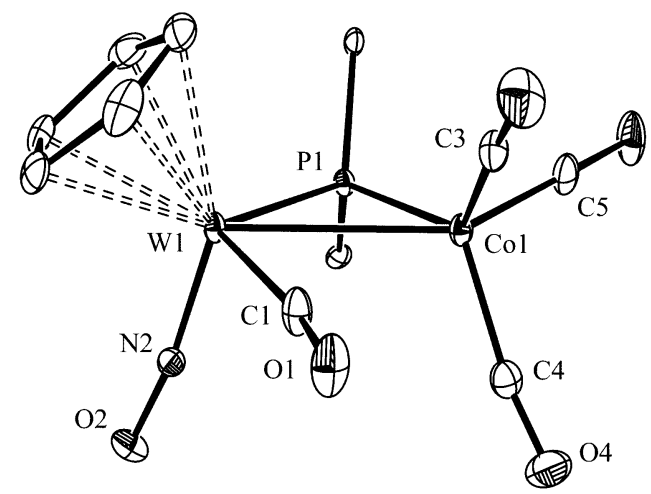

Figure 5. ORTEP diagram (30\% probability) of compound 6, with $\mathrm{H}$ atoms and $\mathrm{Ph}$ rings (except their $\mathrm{C}^{1}$ atoms) omitted for clarity.

Table 4. Selected bond lengths $(\AA)$ and angles $\left(^{\circ}\right)$ for compound 6

\begin{tabular}{llll}
\hline W1-Co1 & $2.8623(6)$ & W1-P1-Co1 & $77.52(3)$ \\
W1-P1 & $2.393(1)$ & P1-W1-C1 & $110.8(1)$ \\
Co1-P1 & $2.171(1)$ & P1-W1-N2 & $96.5(1)$ \\
W1-C1 & $2.010(4)$ & P1-Co1-C3 & $127.2(2)$ \\
W1-N2 & $1.798(3)$ & P1-Co1-C4 & $120.1(1)$ \\
Co1-C3 & $1.787(4)$ & P1-Co1-C5 & $87.2(1)$ \\
Co1-C4 & $1.807(5)$ & C1-W1-N2 & $90.6(2)$ \\
Co1-C5 & $1.744(4)$ & C3-Co1-C4 & $109.6(2)$ \\
& & C3-Co1-C5 & $99.7(2)$ \\
\hline
\end{tabular}

Spectroscopic data for $\mathbf{6}$ in solution are consistent with the structure found in the crystal and deserve only a few comments. As expected, its IR spectrum displays four $\mathrm{C}-\mathrm{O}$ stretches and one $\mathrm{N}-\mathrm{O}$ stretch, with the three strong $\mathrm{C}-\mathrm{O}$ stretches between 2036 and $1965 \mathrm{~cm}^{-1}$ being characteristic of pyramidal $\mathrm{M}(\mathrm{CO})_{3}$ oscillators and comparable to those measured for the mentioned phosphinidene-bridged MoCo complex, therefore being assigned to the $\mathrm{Co}(\mathrm{CO})_{3}$ fragment of the molecule. Its ${ }^{31} \mathrm{P}$ NMR spectrum displays a resonance at $195.3 \mathrm{ppm}$, a position more deshielded than those of complexes 2 to 6, as expected when comparing $\mathrm{PR}_{2}$ ligands involved in bridging with lighter metal atoms (W-Co vs. W-W) ${ }^{36}$ We finally note that the coupling of $408 \mathrm{~Hz}$ to the ${ }^{183} \mathrm{~W}$ nucleus is significantly higher than those found in any other compound in this work (Table 3), an indication of strong $\mathrm{W}-\mathrm{P}$ binding in line with the relatively short $\mathrm{W}-\mathrm{P}$ distance of 2.393(1) A measured in the crystal, slightly below the average separations of ca. 2.41 $\AA$ measured for the $\mathrm{W}-\mathrm{P}-\mathrm{W}$ connections in complexes $\mathbf{2}, \mathbf{3}$ and $\mathbf{7}$.

\section{Structure and solution dynamics of cluster 7}

The molecule of 7 in the crystal (Figure 6 and Table 5) can be derived from that of the parent compound 2 after replacing the hydride ligand with a bridging $\mathrm{Co}(\mathrm{CO})_{4}$ fragment which, however, adopts a quite asymmetric binding to the ditungsten centre which also involves two of the carbonyl ligands. In fact, the $\mathrm{C} 3-\mathrm{O} 3$ ligand can be described as semibridging to the $\mathrm{W} 1$ atom $\left(\mathrm{Co}-\mathrm{C} 3-\mathrm{O} 3\right.$ ca. $153^{\circ}, \mathrm{W} 1-\mathrm{C} 3$ ca. $2.40 \AA$ ) while the $\mathrm{C} 4-\mathrm{O} 4$ ligand binds the $\mathrm{W} 2$ atom in an almost conventional bridging way (Co-C4-O4 
ca. $140^{\circ}, \mathrm{W} 2-\mathrm{C} 4$ ca. $2.23 \AA$ ). Not surprisingly, then, the phosphanyl ligand also displays an asymmetric binding to the tungsten atoms that balances in part the distinct interaction of the carbonyls with these atoms, with the W1-P bond being ca. $0.07 \AA$ shorter than W2-P. Apart from this, we note that the $\mathrm{W}_{2} \mathrm{Cp}_{2}(\mathrm{NO})_{2}$ moiety displays the distorted transoid arrangement observed in clusters 2 and $\mathbf{3}(\mathrm{N}-\mathrm{W}-\mathrm{W}$ angles ca. 87 and $114^{\circ}$ ), and the heavy atom central skeleton is quite puckered, with a $\mathrm{P}-\mathrm{W}-\mathrm{W}-\mathrm{Co}$ angle of ca. $153^{\circ}$.

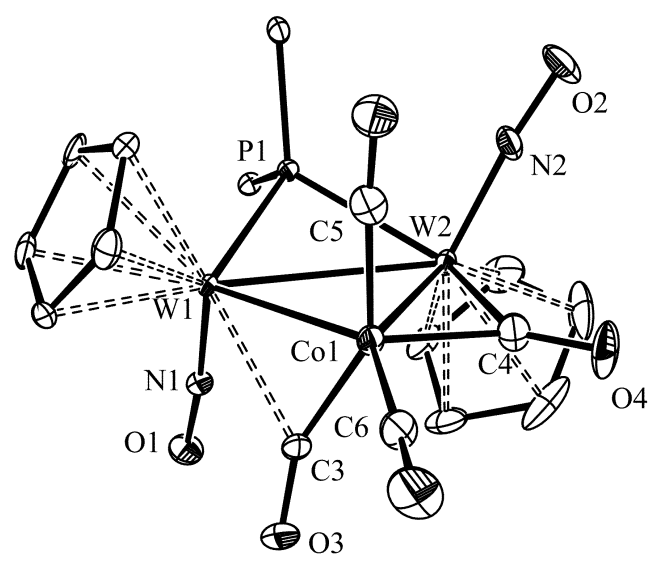

Figure 6. ORTEP diagram ( $30 \%$ probability) of compound 7, with $\mathrm{H}$ atoms and $\mathrm{Ph}$ rings (except their $\mathrm{C}^{1}$ atoms) omitted for clarity.

\begin{tabular}{|c|c|c|c|}
\hline W1-W2 & $3.1654(4)$ & W1-P1-W2 & $81.84(5)$ \\
\hline W1-Co1 & $2.638(1)$ & N1-W1-W2 & $87.0(2)$ \\
\hline W2-Co1 & $2.829(1)$ & N2-W2-W1 & $114.1(2)$ \\
\hline W1-P1 & $2.380(2)$ & $\mathrm{Co} 1-\mathrm{C} 3-\mathrm{O} 3$ & $152.8(6)$ \\
\hline W2-P1 & $2.452(2)$ & $\mathrm{Co} 1-\mathrm{C} 4-\mathrm{O} 4$ & $139.9(7)$ \\
\hline W1-N1 & $1.791(6)$ & W2-C4-O4 & $132.7(7)$ \\
\hline W2-N2 & $1.790(6)$ & C3-Co1-C4 & $111.4(4)$ \\
\hline Co1-C3 & $1.820(8)$ & C3-Co1-C5 & $148.5(4)$ \\
\hline W1-C3 & $2.395(7)$ & C4-Co1-C6 & $95.9(4)$ \\
\hline Co1-C4 & $1.850(8)$ & C5-Co1-C6 & $100.4(4)$ \\
\hline W2-C4 & $2.230(7)$ & $\mathrm{P}-\mathrm{W}-\mathrm{W}-\mathrm{Co}$ & $152.6(1)$ \\
\hline Co1-C5 & 1.791(9) & & \\
\hline Co1-C6 & $1.763(8)$ & & \\
\hline
\end{tabular}

Compound 7 can be classified as an electron-precise (48 valence electrons) trinuclear cluster, therefore single intermetallic bonds should be formulated for this molecule, which is in good agreement with the intermetallic distances of 3.1654(4) $\AA$ (W1-W2) and 2.829(1) $\AA$ (W2-Co). However, the W1-Co separation of 2.638(1) $\AA$ falls on the lower edge of the range observed for Co-M single bonds $(\mathrm{M}=\mathrm{Mo}, \mathrm{W})$, for not obvious reason. We note that similar or even shorter lengths have been measured in related electron-precise tetrahedral clusters such as $\left[\mathrm{Co}_{3} \mathrm{MoCp}\left(\mu_{3}-\mathrm{PR}\right)(\mathrm{CO})_{9}\right](\mathrm{Mo}-\mathrm{Co}$ ca. 2.65 $\left.\AA, \mathrm{R}=2,4,6-\mathrm{C}_{6} \mathrm{H}_{2}{ }^{t} \mathrm{Bu}_{3},{ }^{35} \mathrm{~N}^{i} \mathrm{Pr}_{2}\right),{ }^{37}$ and $\left[\mathrm{Co}_{2} \mathrm{Mo}_{2} \mathrm{Cp}_{2}(\mu-\mathrm{COMe})(\mu-\mathrm{PCy})(\mu-\mathrm{CO})(\mathrm{CO})_{6}\right]$ (2.582(1) $\AA$ ) ${ }^{38}$ These short distances, however, were related at the time with the presence of two semibridging carbonyls over the corresponding Mo-Co edges, a 
circumstance not met in the case of compound 7. For comparison, the Mo-Co lengths in $\left[\mathrm{CoMo}_{2} \mathrm{Cp}_{2}\left(\mu_{3}-\mathrm{CH}\right)(\mathrm{CO})_{7}\right]$, a $\mathrm{CoMo}_{2}$ cluster with no bridging carbonyls, were $2.7169(3)$ and 2.7679(4) $\AA^{39}$

The IR spectrum of 7 in solution displays four C-O stretches at 2037 (vs), 1987 (m), 1838 (w) and 1795 (w) $\mathrm{cm}^{-1}$. The high frequency and intensity of the first two bands allows their identification with the vibrations of the two terminal carbonyls bound to the Co atom, while the low frequency and intensity of the last two bands allows their assignment to the bridging and semibridging carbonyls found in the solid-state structure of the cluster, therefore suggesting that such asymmetric structure is retained in solution. However, the ${ }^{1} \mathrm{H}$ NMR spectrum of 7 displays a single $\mathrm{Cp}$ resonance, and its ${ }^{31} \mathrm{P}$ NMR resonance ( $\delta \mathrm{P} 163.4 \mathrm{ppm}$ ) exhibits a coupling of $288 \mathrm{~Hz}$ to both ${ }^{183} \mathrm{~W}$ nuclei, all of which suggests either the presence of dynamic effects or the adoption in solution of a more symmetrical structure with two equivalent bridging or semibridging carbonyls. The latter possibility can be excluded since a DFT optimization of the structure of 7 yielded a minimum with geometrical parameters comparable to the ones determined in the X-ray diffraction study (Figure 7 and ESI). Therefore we conclude that cluster 7 undergoes a carbonyl exchange process combined with a flapping movement of the puckered $\mathrm{PW}_{2} \mathrm{Co}$ core (comparable to the ones proposed for the hydride clusters 2 and 3 ) which eventually would render an apparent $C_{2}$ symmetry element relating the inequivalent $\mathrm{WCp}(\mathrm{NO})$ fragments, although we have not investigated these structural rearrangements.

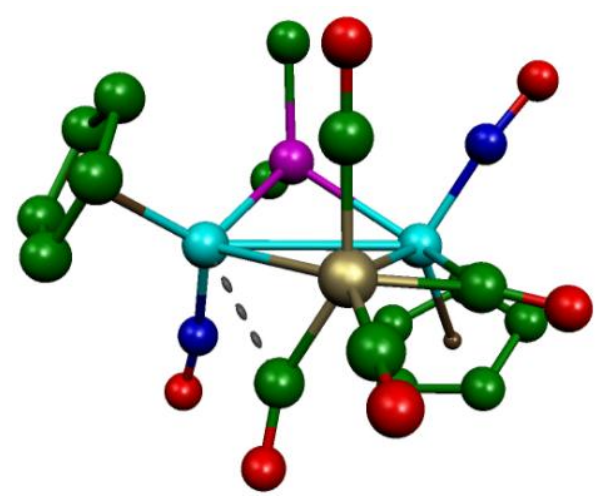

Figure 7. B3LYP DFT-optimized structure of compound 7 with $\mathrm{H}$ atoms and $\mathrm{Ph}$ groups (except their $\mathrm{C}^{1}$ atoms) omitted for clarity, and labelling as shown in Figure 6. Selected bond lengths $(\AA)$ : W1-W2 = 3.253; W1-Co = 2.681; W2-Co = 2.887; W1-C3 = 2.386; Co-C3 = 1.813; W2-C4 = 2.196; Co-C4 = 1.877. $\mathrm{P}-\mathrm{W} 1-\mathrm{W} 2-\mathrm{Co}=144.8^{\circ}$.

\section{Concluding Remarks}

The unsaturated hydride 1 behaves as a useful building block for the rational synthesis of heterometallic clusters with triangular $\mathrm{W}_{2} \mathrm{M}$ cores and bearing both $\mathrm{NO}$ and $\mathrm{CO}$ ligands. Its reactions with suitable precursors of 16-electron metal carbonyl fragments may result in the formation of edge-bridged $\left(\mathrm{W}_{2} \mathrm{Fe}\right)$ or face-bridged $\left(\mathrm{W}_{3}, \mathrm{~W}_{2} \mathrm{Mo}\right.$, 
$\mathrm{W}_{2} \mathrm{Mn}$ ) hydride derivatives, which can be interpreted as resulting from a $\mathrm{CH}_{2}-$ or $\mathrm{H}^{+}$like behaviour of the added fragment, respectively. This is reliably reflected in the observation of shorter $\mathrm{W}-\mathrm{W}$ lengths in the second case, a trend also reproduced by DFT calculations on these clusters. The hydride ligand has a high mobility in most of these clusters, and its most singular rearrangement also involves the heavy-atom core, it being a flapping motion of the central $\mathrm{PW}_{2} \mathrm{M}$ skeleton at the face-bridged isomer which likely proceeds through a transition state displaying a planar trigonal $\mathrm{PW}_{2} \mathrm{M}\left(\mu_{3}-\mathrm{H}\right)$ core with weakened $\mathrm{W}-\mathrm{M}$ interactions. The photochemical reactions of $\mathbf{1}$ with suitable precursors of 17-electron metal carbonyl fragments were hampered by degradation and easy carbonylation of $\mathbf{1}$ under photolytic conditions. Yet, the potential of this synthetic approach in dark conditions was proved through the reaction of 1 with $\left[\mathrm{Co}_{2}(\mathrm{CO})_{8}\right]$, which led to the expected $\mathrm{W}_{2}$ Co cluster resulting from formal replacement of the bridging hydride with a 17-electron metal fragment.

\section{Experimental Section}

\section{General procedures and starting materials}

All manipulations and reactions were carried out under an argon (99.995\%) atmosphere using standard Schlenk techniques. All experiments were carried out using Schlenk tubes equipped with Young's valves. Solvents were purified according to literature procedures and distilled prior to use. ${ }^{40}$ Petroleum ether refers to that fraction distilling in the range $338-343 \quad \mathrm{~K}$. Complexes $\quad\left[\mathrm{W}_{2} \mathrm{Cp}_{2}(\mu-\mathrm{H})\left(\mu-\mathrm{PPh}_{2}\right)(\mathrm{NO})_{2}\right] \quad(\mathbf{1}){ }^{7}$ $\left[\mathrm{MnCp}(\mathrm{CO})_{2}(\mathrm{THF})\right]\left(\mathrm{Cp}^{\prime}=\mathrm{C}_{5} \mathrm{H}_{4} \mathrm{Me}\right),{ }^{41}$ and $\left[\mathrm{M}(\mathrm{CO})_{5}(\mathrm{THF})\right](\mathrm{M}=\mathrm{Mo}, \mathrm{W}),{ }^{42}$ were prepared as described previously, while all other reagents were obtained from the usual commercial suppliers and used as received, unless otherwise stated. Photochemical experiments were performed using jacketed Schlenk tubes cooled by tap water (ca. 288 $\mathrm{K}$ ). A $400 \mathrm{~W}$ medium-pressure mercury lamp (as source of visible-UV light) or a conventional $200 \mathrm{~W}$ lamp (as source of visible light), both placed ca. $1 \mathrm{~cm}$ away from the Schlenk tube, were used for these experiments. Chromatographic separations were carried out using jacketed columns cooled by tap water (ca. $288 \mathrm{~K}$ ) or by a closed 2propanol circuit, kept at the desired temperature with a cryostat. Commercial aluminium oxide (activity I, 70-290 mesh) was degassed under vacuum prior to use. The latter was mixed under argon with the appropriate amount of water to reach activity IV. IR stretching frequencies were measured in solution, are referred to as $v$ (solvent), and are given in $\mathrm{cm}^{-1}$. Nuclear magnetic resonance (NMR) spectra were routinely recorded at $293 \mathrm{~K}$ unless otherwise stated. Chemical shifts $(\delta)$ are given in ppm, relative to internal tetramethylsilane $\left({ }^{1} \mathrm{H},{ }^{13} \mathrm{C}\right)$, or external $85 \%$ aqueous $\mathrm{H}_{3} \mathrm{PO}_{4}\left({ }^{31} \mathrm{P}\right)$, and coupling constants $(J)$ are given in $\mathrm{Hz}$. 
Preparation of $\left[\mathrm{FeW}_{2} \mathrm{Cp}_{2}(\mu-\mathrm{H})\left(\mu-\mathrm{PPh}_{2}\right)(\mathbf{C O})_{4}(\mathrm{NO})_{2}\right]$ (2). Solid $\left[\mathrm{Fe}_{2}(\mathrm{CO})_{9}\right](0.040$ $\mathrm{g}, 0.110 \mathrm{mmol})$ was added to a toluene solution $(10 \mathrm{~mL})$ of compound $1(0.040 \mathrm{~g}, 0.054$ $\mathrm{mmol}$ ), and the mixture was stirred at $293 \mathrm{~K}$ for $1 \mathrm{~h}$ to give a red solution. The solvent was then removed under vacuum, the residue extracted with dichloromethane/petroleum ether (1/3), and the extracts chromatographed on alumina at $253 \mathrm{~K}$. Elution with dichloromethane/petroleum ether (1/1) gave a red fraction yielding, after removal of solvents, compound 2 as a red microcrystalline solid $(0.020 \mathrm{~g}, 41 \%)$. The crystals used in the X-ray diffraction study were grown through the slow diffusion of layers of toluene and petroleum ether into a concentrated dichloromethane solution of the complex at $253 \mathrm{~K}$. Anal. Calcd for $\mathrm{C}_{26} \mathrm{H}_{21} \mathrm{~N}_{2} \mathrm{O}_{6} \mathrm{PFeW}_{2}$ : C, 34.24; H, 2.32; N, 3.07. Found: C, 33.98; H, 2.33; N, 2.86. ${ }^{1} \mathrm{H}$ NMR (300.13 MHz, $\left.\mathrm{CD}_{2} \mathrm{Cl}_{2}, 293 \mathrm{~K}\right): \delta 7.50-7.37$ $(\mathrm{m}, 10 \mathrm{H}, \mathrm{Ph}), 5.28\left(\mathrm{~d}, J_{\mathrm{PH}}=1,10 \mathrm{H}, \mathrm{Cp}\right),-11.95\left(\mathrm{~d}, J_{\mathrm{HP}}=9, J_{\mathrm{HW}}=32,1 \mathrm{H}, \mu-\mathrm{H}\right) .{ }^{1} \mathrm{H}$ NMR (600.15 MHz, $\mathrm{CD}_{2} \mathrm{Cl}_{2}, 184 \mathrm{~K}$ ): $\delta$ 7.80-7.20 (m, 10H, Ph), 5.33 (s, 10H, Cp), -12.75 (s, br, $1 \mathrm{H}, \mu-\mathrm{H}) .{ }^{13} \mathrm{C}\left\{{ }^{1} \mathrm{H}\right\}$ NMR $\left(150.91 \mathrm{MHz}, \mathrm{CD}_{2} \mathrm{Cl}_{2}, 213 \mathrm{~K}\right): \delta 210.8(\mathrm{~s}, \mathrm{br}$, $4 \mathrm{FeCO}), 142.5\left[\mathrm{~d}, J_{\mathrm{CP}}=48, \mathrm{C}^{1}(\mathrm{Ph})\right], 134.0\left[\mathrm{~d}, J_{\mathrm{CP}}=9, \mathrm{C}^{2}(\mathrm{Ph})\right], 130.0\left[\mathrm{~s}, \mathrm{C}^{4}(\mathrm{Ph})\right], 129.0$ $\left[\mathrm{d}, J_{\mathrm{CP}}=10, \mathrm{C}^{3}(\mathrm{Ph})\right], 95.7(\mathrm{~s}, \mathrm{Cp})$.

Preparation of $\left[\mathrm{W}_{3} \mathrm{Cp}_{2}\left(\mu_{3}-\mathrm{H}\right)\left(\mu-\mathrm{PPh}_{2}\right)(\mathrm{CO})_{5}(\mathrm{NO})_{2}\right] \quad$ (3). A solution of $\left[\mathrm{W}(\mathrm{CO})_{5}(\mathrm{THF})\right]$ was prepared in situ upon irradiation of a tetrahydrofuran solution (5 $\mathrm{mL})$ of $\left[\mathrm{W}(\mathrm{CO})_{6}\right](0.025 \mathrm{~g}, 0.072 \mathrm{mmol})$ with visible-UV light at $288 \mathrm{~K}$, then transferred into a Schlenk tube containing solid compound 1 ( $0.040 \mathrm{~g}, 0.054 \mathrm{mmol})$. The solvent was then removed under vacuum, the residue dissolved in toluene and the mixture stirred at $293 \mathrm{~K}$ for $5 \mathrm{~min}$ to give a red solution. After removal of the solvent again, the residue was extracted with dichloromethane/petroleum ether (1/2), and the extracts chromatographed on alumina at 288 K. Elution with dichloromethane/petroleum ether (1/1) gave a rose fraction yielding, after removal of solvents, compound 3 as a red microcrystalline solid $(0.035 \mathrm{~g}, 60 \%)$. The crystals used in the X-ray diffraction study were grown through the slow diffusion of layers of toluene and petroleum ether into a concentrated dichloromethane solution of the complex at $253 \mathrm{~K}$. Anal. Calcd for $\mathrm{C}_{27} \mathrm{H}_{21} \mathrm{~N}_{2} \mathrm{O}_{7} \mathrm{PW}_{3}$ : C, 30.37; H, 1.98; N, 2.62. Found: $\mathrm{C}, 30.65 ; \mathrm{H}, 2.13$; N, 2.67. ${ }^{1} \mathrm{H}$ NMR $\left(300.13 \mathrm{MHz}, \mathrm{CD}_{2} \mathrm{Cl}_{2}, 293 \mathrm{~K}\right): \delta 7.62-7.30(\mathrm{~m}$, $10 \mathrm{H}, \mathrm{Ph}), 5.43\left(\mathrm{~d}, J_{\mathrm{PH}}=1,10 \mathrm{H}, \mathrm{Cp}\right),-5.69\left(\mathrm{~d}, J_{\mathrm{HP}}=7, J_{\mathrm{HW}}=74,74,40,1 \mathrm{H}, \mu_{3}-\mathrm{H}\right) .{ }^{1} \mathrm{H}$ NMR (400.13 MHz, $\mathrm{CD}_{2} \mathrm{Cl}_{2}, 173 \mathrm{~K}$ ): $\delta$ 7.60-6.80 (m, 10H, Ph), 5.50 (s, 10H, Cp), $-5.23\left(\mathrm{~d}, J_{\mathrm{HP}}=8, J_{\mathrm{HW}}=71,71,40,1 \mathrm{H}, \mu_{3}-\mathrm{H}\right) .{ }^{13} \mathrm{C}\left\{{ }^{1} \mathrm{H}\right\} \mathrm{NMR}\left(100.61 \mathrm{MHz}, \mathrm{CD}_{2} \mathrm{Cl}_{2}\right)$ : $\delta 200.9\left(\mathrm{~s}, \mathrm{WCO}_{\mathrm{ax}}\right), 198.8\left(\mathrm{~s}, \mathrm{WCO}_{\mathrm{eq}}\right), 140.2\left[\mathrm{~d}, J_{\mathrm{PC}}=50, \mathrm{C}^{1}(\mathrm{Ph})\right], 134.1\left[\mathrm{~d}, J_{\mathrm{CP}}=11\right.$, $\left.\mathrm{C}^{2}(\mathrm{Ph})\right], 130.4\left[\mathrm{~d}, J_{\mathrm{CP}}=3, \mathrm{C}^{4}(\mathrm{Ph})\right], 129.3\left[\mathrm{~d}, J_{\mathrm{CP}}=11, \mathrm{C}^{3}(\mathrm{Ph})\right], 98.1(\mathrm{~s}, \mathrm{Cp})$.

Preparation of $\left[\mathrm{MoW}_{2} \mathrm{Cp}_{2}\left(\mu_{3}-\mathbf{H}\right)\left(\mu-\mathrm{PPh}_{2}\right)(\mathbf{C O})_{5}(\mathbf{N O})_{2}\right]$ (4). The procedure is analogous to the one described for 3 , but using a solution of $\left[\mathrm{Mo}(\mathrm{CO})_{5}(\mathrm{THF})\right]$ (ca. 0.75 mmol) instead. This yielded a mixture of compounds 4 and $\left[\mathrm{W}_{2} \mathrm{Cp}_{2} \mathrm{H}(\mu-\right.$ 
$\left.\left.\mathrm{PPh}_{2}\right)(\mathrm{CO})(\mathrm{NO})_{2}\right]$ as major products, in a ratio of ca 1:2. Attempts to isolate compound 4 from these mixtures were unsuccessful due to its progressive decomposition. ${ }^{1} \mathrm{H}$ NMR (300.13 MHz, $\left.\mathrm{CD}_{2} \mathrm{Cl}_{2}\right): \delta 7.95-6.65(\mathrm{~m}, 10 \mathrm{H}, \mathrm{Ph}), 5.31\left(\mathrm{~d}, J_{\mathrm{PH}}=1,10 \mathrm{H}, \mathrm{Cp}\right),-7.05(\mathrm{~d}$, $\left.J_{\mathrm{HP}}=5, J_{\mathrm{HW}}=82,1 \mathrm{H}, \mu_{3}-\mathrm{H}\right)$.

Preparation of $\left[\mathrm{MnW}_{2} \mathrm{Cp}_{2} \mathrm{Cp}^{\prime}\left(\mu_{3}-\mathrm{H}\right)\left(\mu-\mathrm{PPh}_{2}\right)(\mathrm{CO})_{2}(\mathrm{NO})_{2}\right]$ (5). A solution of $\left.[\mathrm{MnCp} \text { '(CO) })_{2}(\mathrm{THF})\right]$ was prepared in situ upon irradiation of a tetrahydrofuran solution $(5 \mathrm{~mL})$ of [MnCp' $\left.(\mathrm{CO})_{3}\right](0.015 \mu \mathrm{L}, 0.095 \mathrm{mmol})$ with visible-UV light at $288 \mathrm{~K}$, then transferred into a flask containing solid compound $1(0.040 \mathrm{~g}, 0.054 \mathrm{mmol})$. The solvent was then removed under vacuum, the residue dissolved in toluene and the mixture stirred at $293 \mathrm{~K}$ for $5 \mathrm{~min}$ to give a red solution. After removal of the solvent again, the residue was extracted with dichloromethane/petroleum ether (1/2), and the extracts were chromatographed on alumina at $288 \mathrm{~K}$. Elution with dichloromethane/petroleum ether (1/1) gave a rose fraction yielding, after removal of solvents, compound $\mathbf{5}$ as a red microcrystalline solid $(0.021 \mathrm{~g}, 42 \%)$. Anal. Calcd for $\mathrm{C}_{30} \mathrm{H}_{28} \mathrm{~N}_{2} \mathrm{O}_{4} \mathrm{PMnW}_{2}$ : C, 38.57; $\mathrm{H}$, 3.02; N, 3.00. Found: C, 38.40; H, 2.86; N, 2.81. ${ }^{1} \mathrm{H}$ NMR (300.13 MHz, $\left.\mathrm{CD}_{2} \mathrm{Cl}_{2}\right): \delta$ 7.70-7.25 (m, 10H, Ph), 5.46, 5.28 (2s, 2 x 5H, Cp), 5.25, 4.81, 4.42, $4.29(4 \mathrm{~m}, 4$ x 1H, $\left.\mathrm{C}_{5} \mathrm{H}_{4}\right), 2.29\left(\mathrm{~s}, 3 \mathrm{H}, \mathrm{CH}_{3}\right),-7.67\left(\mathrm{~d}, J_{\mathrm{HP}}=2, J_{\mathrm{HW}}=80,1 \mathrm{H}, \mu_{3}-\mathrm{H}\right) .{ }^{13} \mathrm{C}\left\{{ }^{1} \mathrm{H}\right\}$ NMR $(75.46$ $\left.\mathrm{MHz}, \mathrm{CD}_{2} \mathrm{Cl}_{2}\right): \delta 232.4,230.4(2 \mathrm{~s}, \mathrm{MnCO}), 144.5\left[\mathrm{~d}, J_{\mathrm{CP}}=40, \mathrm{C}^{1}(\mathrm{Ph})\right], 135.0\left[\mathrm{~d}, J_{\mathrm{CP}}=\right.$ 9, $\left.\mathrm{C}^{2}(\mathrm{Ph})\right], 133.5\left[\mathrm{~d}, J_{\mathrm{CP}}=11, \mathrm{C}^{2}(\mathrm{Ph})\right], 130.2,129.4\left[2 \mathrm{~s}, \mathrm{C}^{4}(\mathrm{Ph})\right], 129.2\left[\mathrm{~d}, J_{\mathrm{CP}}=11\right.$, $\left.\mathrm{C}^{3}(\mathrm{Ph})\right], 128.7\left[\mathrm{~d}, J_{\mathrm{CP}}=10, \mathrm{C}^{3}(\mathrm{Ph})\right], 98.6,95.8(2 \mathrm{~s}, \mathrm{Cp}), 84.7,84.5,83.1,82.0[4 \mathrm{~s}$, $\left.\mathrm{CH}\left(\mathrm{C}_{5} \mathrm{H}_{4}\right)\right], 14.0\left(\mathrm{~s}, \mathrm{CH}_{3}\right)$; one of the $\mathrm{C}^{1}(\mathrm{Ph})$ resonances and the $\mathrm{C}^{1}\left(\mathrm{C}_{5} \mathrm{H}_{4}\right)$ resonance could not be identified in this spectrum.

Reaction of compound 1 with $\left[\mathrm{Co}_{2}(\mathbf{C O})_{8}\right]$. A toluene solution $(20 \mathrm{~mL})$ of compound $1(0.060 \mathrm{~g}, 0.080 \mathrm{mmol})$ was frozen with liquid nitrogen. Solid $\left[\mathrm{Co}_{2}(\mathrm{CO})_{8}\right]$ $(0.028 \mathrm{~g}, 0.082 \mathrm{mmol})$ was then added, the Schlenk tube set under vacuum and then its Young's valve closed. The mixture was then allowed to melt and stirred at $253 \mathrm{~K}$ for 30 min. Upon removal of solvent under vacuum, the residue was washed with petroleum ether $(4 \mathrm{x} 5 \mathrm{~mL})$ to remove some cobalt by-products, then extracted with dichloromethane/petroleum ether (1/3), and the extracts chromatographed on alumina at $253 \mathrm{~K}$. Elution with the same solvent mixture gave an orange fraction yielding, after removal of solvents, compound $\left[\mathrm{CoWCp}\left(\mu-\mathrm{PPh}_{2}\right)(\mathrm{CO})_{4}(\mathrm{NO})\right](6)$ as an orange microcrystalline solid $(0.010 \mathrm{~g}, 19 \%)$. The crystals used in the X-ray diffraction study were grown through the slow diffusion of a layer of petroleum ether into a concentrated toluene solution of the complex at $273 \mathrm{~K}$. Elution with dichloromethane/petroleum ether $(1 / 1)$ gave a red fraction yielding analogously compound $\left[\mathrm{CoW}_{2} \mathrm{Cp}_{2}(\mu-\right.$ $\left.\left.\mathrm{PPh}_{2}\right)(\mathrm{CO})_{4}(\mathrm{NO})_{2}\right](7)$ as a red solid $(0.022 \mathrm{~g}, 30 \%)$. The crystals used in the X-ray diffraction study were grown through the slow diffusion of a layer of petroleum ether into a concentrated dichloromethane solution of the complex at 253 K. Data for 6: Anal. 
Calcd for $\mathrm{C}_{21} \mathrm{H}_{15} \mathrm{NO}_{5} \mathrm{PCoW}$ : C, 39.72; H, 2.38; N, 2.21. Found: C, 39.47; H, 2.10; N, 2.05. ${ }^{1} \mathrm{H}$ NMR (300.13 MHz, $\mathrm{CD}_{2} \mathrm{Cl}_{2}$ ): $\delta 7.65-7.35$ (m, 10H, Ph), 5.40 (s, 5H, Cp). Data for 7: Anal. Calcd for $\mathrm{C}_{26} \mathrm{H}_{20} \mathrm{~N}_{2} \mathrm{O}_{6} \mathrm{PCoW}_{2}$ : C, 34.17; H, 2.21; N, 3.07. Found: C, 33.85; $\mathrm{H}, 2.12 ; \mathrm{N}, 2.97 .{ }^{1} \mathrm{H}$ NMR $\left(300.13 \mathrm{MHz}, \mathrm{CD}_{2} \mathrm{Cl}_{2}\right): \delta 7.65-7.30(\mathrm{~m}, 10 \mathrm{H}, \mathrm{Ph}), 5.26(\mathrm{~s}$, $10 \mathrm{H}, \mathrm{Cp})$.

Table 6. Crystal data for new compounds.

\begin{tabular}{|c|c|c|c|c|}
\hline & 2 & 3 & 6 & 7 \\
\hline mol formula & $\mathrm{C}_{26} \mathrm{H}_{21} \mathrm{Fe} \mathrm{N}{ }_{2} \mathrm{O}_{6} \mathrm{PW}_{2}$ & $\mathrm{C}_{27} \mathrm{H}_{21} \mathrm{~N}_{2} \mathrm{O}_{7} \mathrm{PW}_{3}$ & $\mathrm{C}_{21} \mathrm{H}_{15} \mathrm{NCoO}_{5} \mathrm{PW}$ & $\mathrm{C}_{26} \mathrm{H}_{20} \mathrm{CoN}_{2} \mathrm{O}_{6} \mathrm{PW}_{2}$ \\
\hline mol wt & 911.95 & 1067.98 & 635.08 & 914.04 \\
\hline cryst syst & triclinic & triclinic & monoclinic & triclinic \\
\hline space group & $P-1$ & $P-1$ & $P 2_{1} / c$ & $P-1$ \\
\hline radiation $(\lambda, \AA)$ & 1.54184 & 1.54184 & 1.54184 & 1.54184 \\
\hline$a, \AA$ & $9.0165(6)$ & $9.0754(5)$ & $8.8952(1)$ & $9.2375(4)$ \\
\hline$b, \AA$ & $10.2932(8)$ & $10.9594(6)$ & $14.2981(1)$ & $9.7923(4)$ \\
\hline$c, \AA$ & $15.2472(10)$ & $14.9036(6)$ & $16.4401(2)$ & $15.4405(6)$ \\
\hline$\alpha, \operatorname{deg}$ & $72.022(6)$ & $102.888(4)$ & 90 & $72.621(4)$ \\
\hline$\beta, \operatorname{deg}$ & $86.303(5)$ & $93.925(4)$ & $93.065(1)$ & $88.180(3)$ \\
\hline$\gamma, \operatorname{deg}$ & $82.979(6)$ & $94.326(5)$ & 90 & $83.018(3)$ \\
\hline$V, \AA^{3}$ & $1335.35(17)$ & $1435.31(13)$ & 2087.93(4) & $1323.03(10)$ \\
\hline $\mathrm{Z}$ & 2 & 2 & 4 & 2 \\
\hline calcd density, $\mathrm{g} \mathrm{cm}^{-3}$ & 2.268 & 2.471 & 2.020 & 2.294 \\
\hline absorp coeff, $\mathrm{mm}^{-1}$ & 20.819 & 22.67 & 17.124 & 21.526 \\
\hline temperature, $\mathrm{K}$ & $151(2)$ & $155(4)$ & $154(1)$ & $152(2)$ \\
\hline$\theta$ range (deg) & $4.54-69.54$ & $4.16-69.74$ & $4.10-69.62$ & $3.00-69.69$ \\
\hline index ranges $(h, k, l)$ & $\begin{array}{l}-10,10 ;-12,12 \\
-18,15\end{array}$ & $\begin{array}{l}-10,10 ;-10,13 \\
-18,16\end{array}$ & $\begin{array}{l}-10,10 ;-12,17 \\
-14,19\end{array}$ & $\begin{array}{l}-11,10 ;-11,11 \\
-18,18\end{array}$ \\
\hline no. of reflns collected & 10615 & 9911 & 10245 & 18070 \\
\hline no. of indep reflns $\left(R_{\text {int }}\right)$ & $4911(0.0452)$ & $5205(0.0565)$ & $3854(0.0385)$ & 4907 (0.0959) \\
\hline no. of reflns with $I>2 \sigma(I)$ & 4099 & 4446 & 3700 & 4554 \\
\hline $\begin{array}{l}R \text { indexes } \\
{[\text { data with } I>2 \sigma(I)]^{a}}\end{array}$ & $\begin{array}{l}R_{1}=0.0919 \\
\mathrm{w} R_{2}=0.2380^{b}\end{array}$ & $\begin{array}{l}R_{1}=0.0847 \\
\mathrm{w} R_{2}=0.2401^{c}\end{array}$ & $\begin{array}{l}R_{1}=0.0324 \\
\mathrm{w} R_{2}=0.0827^{d}\end{array}$ & $\begin{array}{l}R_{1}=0.0553 \\
\mathrm{w} R_{2}=0.1417^{e}\end{array}$ \\
\hline$R$ indexes (all data) ${ }^{a}$ & $\begin{array}{l}R_{1}=0.1026 \\
\mathrm{w} R_{2}=0.2461^{b}\end{array}$ & $\begin{array}{l}R_{1}=0.0919 \\
\mathrm{w} R_{2}=0.2649^{c}\end{array}$ & $\begin{array}{l}R_{1}=0.0336 \\
\mathrm{w} R_{2}=0.0838^{d}\end{array}$ & $\begin{array}{l}R_{1}=0.0582 \\
\mathrm{w} R_{2}=0.1475^{e}\end{array}$ \\
\hline GOF & 1.111 & 1.123 & 1.078 & 1.110 \\
\hline $\begin{array}{l}\text { no. of } \\
\text { restraints/parameters }\end{array}$ & $42 / 347$ & $18 / 354$ & $0 / 271$ & $0 / 343$ \\
\hline$\Delta \rho$ (max., min. $), \mathrm{e}^{-3}$ & $6.587 /-2.745$ & $10.010 /-4.073$ & $1.691 /-1.642$ & $2.058 /-5.185$ \\
\hline CCDC deposition No & 1565767 & 1565768 & 1565769 & 1565770 \\
\hline
\end{tabular}

${ }^{a} R=\Sigma|| F_{o}|-| F_{c} \| / 2\left|F_{o}\right| \cdot w R=\left[\Sigma w\left(\left|F_{o}\right|^{2}-\left|F_{c}\right|^{2}\right)^{2} / \Sigma w\left|\mathrm{~F}_{o}\right|^{2}\right]^{1 / 2} \cdot w=1 /\left[\sigma^{2}\left(F_{o}^{2}\right)+(a P)^{2}+b P\right]$ where $P=\left(F_{o}{ }^{2}+2 F_{c}{ }^{2}\right) / 3 .{ }^{b} a=0.1112, b=53.4617 .{ }^{c} a=0.2000, b=0.0000 .{ }^{d} a=0.0561$, $b=0.0000 .^{e} a=0.1041, b=0.0000$.

\section{X-ray structure determination of compounds 2, 3, 6 and 7}

Data collection was performed at ca. $150 \mathrm{~K}$ on an Oxford Diffraction Xcalibur Nova single crystal diffractometer, using $\mathrm{Cu}-\mathrm{K}_{\alpha}$ radiation. Images were collected at a $62 \mathrm{~mm}$ fixed crystal-detector distance, using the oscillation method and variable exposure time per image. Data collection strategy was calculated with the program CrysAlis Pro $C C D,{ }^{43}$ and data reduction and cell refinement were performed with the program CrysAlis Pro RED. ${ }^{43}$ Empirical absorption corrections were applied using the SCALE3 ABSPACK algorithm as implemented in the latter program. Using the program suite WINGX ${ }^{44}$ the structures were solved by Patterson interpretation and phase expansion using SHELXL2016, and refined with full-matrix least squares on $F^{2}$ using 
SHELXL2016, ${ }^{45}$ to give the residuals collected in Table 6 . Due to poor quality of the diffraction data (in particular, unsolvable twinning was found for 2 ), relatively large residual electron density peaks nearby the metal atoms remained in most cases in the difference maps. In general, all non-hydrogen atoms were refined anisotropically, and all hydrogen atoms were geometrically placed and refined using a riding model. In the case of 2 , the $C(10)$ and $C(11)$ atoms were refined anisotropically in combination with the instructions DELU and SIMU. The hydride ligand in compound $\mathbf{2}$ could not be located in the final difference map, therefore possible positions were investigated by a potential energy minima search using the program HYDEX. ${ }^{46}$ Only one minimum was found, in the vicinity of the W1-Fe bond, consistent with elongation of this bond relative to the $\mathrm{W} 2-\mathrm{Fe}$ bond, so this position was assigned to the hydride ligand and refined isotropically; nevertheless, some restrains had to be applied to the hydride-metal distances to reach a satisfactory refinement. In contrast, the hydride ligand in compound 3 could be located in the final difference map, and then refined isotropically after applying some restraints to the $\mathrm{W}-\mathrm{H}$ distances. For this compound, the $\mathrm{C}(13)$ atom was refined anisotropically in combination with the instructions DELU and SIMU, and two carbonyl $\mathrm{C}$ atoms were refined isotropically to prevent their temperature factors from becoming non-positive definite.

\section{Computational details}

All DFT computations were carried out using the GAUSSIAN03 package, ${ }^{47}$ in which the hybrid method B3LYP was used with the Becke three-parameter exchange functional $^{48}$ and the Lee-Yang-Parr correlation functional. ${ }^{49}$ A pruned numerical integration grid $(99,590)$ was used for all the calculations via the keyword Int=Ultrafine. Effective core potentials and their associated double- $\zeta$ LANL2DZ basis set were used for the metal atoms. ${ }^{50}$ The light elements $(\mathrm{P}, \mathrm{O}, \mathrm{C}, \mathrm{N}$ and $\mathrm{H}$ ) were described with the 6-31G* basis. ${ }^{51}$ Geometry optimizations were performed under no symmetry restrictions, and frequency analyses were performed for all the stationary points to ensure that minimum structures with no imaginary frequencies were achieved. Molecular graphics and vibrational modes were visualized using the Molekel program. ${ }^{52}$

\section{Acknowledgments}

We thank the Gobierno del Principado de Asturias for a grant (to A. T.) and financial support (Project GRUPIN14-011), the MINECO of Spain and FEDER for financial support (Project CTQ2015-63726-P), and the CMC and X-Ray units of the Universidad de Oviedo for access to computing facilities and acquisition of diffraction data, respectively. 


\section{Notes and References}

Departamento de Química Orgánica e Inorgánica / IUQOEM, Universidad de Oviedo, E-33071 Oviedo, Spain.E-mail: garciavdaniel@uniovi.es (D. G. V.), mara@uniovi.es (M.A.R.)

$\dagger$ Electronic supplementary information (ESI) available: A CIF file containing full crystallographic data for compounds 2, 3, 6 and 7 (CCDC 1565767-1565770), a PDF file containing results of DFT calculations (drawings, energies and IR data), and an XYZ file including the Cartesian coordinates for all computed species. See DOI: $10.1039 / \mathrm{b} 000000 \mathrm{x} /$

1. See for example: (a) D. F. Shriver, H. D. Kaesz and R. D. Adams, The Chemistry of Metal Cluster Complexes, VCH, Weinheim, Germany, 1990; (b) R. D. Adams and F. A. Cotton, Catalysis by Di- and Polynuclear Metal Complexes, Wiley-VCH, New York, USA, 1998; (c) P. Braunstein, L. A. Oro and P. R. Raithby, Metal Clusters in Chemistry, Wiley-VCH, Weinheim, Germany, 1999, Vols. 1 and 2.

2. For some work on the $\mathrm{Os}_{3}$ complex, see: (a) K. V. Kong, Z. Lam, W. D. Goh, W. K. Leong and M. Olivo, Angew. Chem. Int. Ed., 2012, 51, 9796; (b) V. P. Kirin, M. Y. Afonin, A. V. Virovets and V. A. Maksakov, J. Coord. Chem., 2012, 38, 273; (c) Y. B. Lee and W. T. Wong, J. Clust. Sci., 2008, 19, 133; (d) C. E. Cooke, T. Ramnial, M. C. Jennings, R. K. Pomeroy and J. A. C. Clyburne, Dalton Trans., 2007, 1755; (e) P. Srinivasan and W. K. Leong, J. Organomet. Chem., 2006, 691, 403 , and references therein.

3. For some work on the $\mathrm{Re}_{2}$ system, see: (a) R. D. Adams, P. Dhull, V. Rassolov and Y. O. Wong, Inorg. Chem., 2016, 55, 10475; (b) S. H. Huang, W. H. Watson, C. J. Carrano, X. Wang and M. G. Richmond, Organometallics, 2010, 29, 61; (c) M. C. Comstock, T. Prussak-Wieckowska, S. R. Wilson and J. R. Shapley, Inorg. Chem., 1997, 36, 4397; (d) M. Bergamo, T. Beringhelli, G. D’Alfonso, P. Mercandelli, M. Moret and A. Sironi, Organometallics, 1997, 16, 4129, and references therein.

4. (a) R. Carreño, V. Riera, M. A. Ruiz, C. Bois and Y. Jeannin, Organometallics, 1992, 11, 4022; (b) R. Carreño, V. Riera, M. A. Ruiz, C. Bois and Y. Jeannin, Organometallics, 1992, 11, 2923; (c) V. Riera, M. A. Ruiz, A. Tiripicchio and M. Tiripicchio-Camellini, Organometallics, 1993, 12, 2962; (d) R. Carreño, V. Riera, M. A. Ruiz, M. Lanfranchi, A. Tiripicchio and M. Tiripicchio-Camellini, Organometallics, 1994, 13, 993.

5. (a) D. García-Vivó, A. Ramos and M. A. Ruiz, Coord. Chem. Rev., 2013, 257, 2143; (b) J. P. Collman and R Boulatov, Angew. Chem. Int. Ed., 2002, 41, 3948; (c) M. J. Winter, Adv. Organomet. Chem., 1989, 29, 101. (d) M. D. Curtis, Polyhedron, $1987,6,759$. 
6. (a) R. Hoffmann, Angew. Chem., Int. Ed. Engl., 1982, 21, 711. (b) F. G. A. Stone, Angew. Chem., Int. Ed. Engl., 1984, 23, 89.

7. M. A. Alvarez, M. E. García, D. García-Vivó, M. A. Ruiz and A. Toyos, Dalton Trans., 2016, 45, 13300.

8. M. E. García, S. Melón, M. A. Ruiz, R. López, T. Sordo, L. Marchiò and A. Tiripicchio, Inorg. Chem., 2008, 47, 10644.

9. (a) M. A. Alvarez, M. E. García, D. García-Vivó, M. A. Ruiz, A. Toyos and M. F. Vega, Inorg. Chem., 2013, 52, 3942; (b) M. E. García, D. García-Vivó, S. Melón, M. A. Ruiz, C. Graiff and A. Tiripicchio, Inorg. Chem., 2009, 48, 9282.

10. D. E. Fjare and W. L. Gladfelter, J. Am. Chem. Soc., 1984, 106, 4799.

11. (a) Reduction of Nitrogen Oxide Emissions, U. S. Ozkan, S. K. Agarwal and G. Marcelin, Eds., American Chemical Society, Washington, DC, 1995; (b) Environmental Catalysis, J. M. Armor, Ed.; American Chemical Society, Washington, DC, 1994; (c) Catalytic Control of Air Pollution, R. G. Silver, J. E. Sawyer and J. C. Summers, Eds., American Chemical Society, Washington, DC 1992; (d) Energy and the Environment, J. Dunderdale, Ed., Royal Society of Chemistry, Cambridge, U. K., 1990; (e) Pollution: Causes, Effects and Control, R. M. Harrison, Ed.; Royal Society of Chemistry, Cambridge, U. K., 1990.

12. (a) F. Liu, Y. Yu and H. He, Chem. Commun., 2014, 50, 8445. (a) P. Granger and V. I. Parvulescu, Chem. Rev., 2011, 111, 3155; (b) S. Basu, Chem. Eng. Commun., 2007, 194, 1374; (c) M. T. Javed, N. Irfan and B. M. Gibbs, J. Environm. Manag., 2007, 83, 251; (d) T. J. Wallington, E. W. Kaiser and J. T. Farrell, Chem. Soc. Rev., 2006, 35, 335 .

13. (a) C. M. Alvarez, M. A. Alvarez, M. E. García, A. Ramos, M. A. Ruiz, M. Lanfranchi and A. Tiripicchio, Organometallics, 2005, 24, 7; (b) M. A. Alvarez, M. E. García, A. Ramos and M. A. Ruiz, Organometallics, 2006, 25, 5374.

14. M. A. Alvarez, M. E. García, D. García-Vivó, M. A. Ruiz and M. F. Vega, Dalton Trans., 2014, 43, 16044.

15. (a) R. B. Calvert and J. R. Shapley, J. Am. Chem. Soc., 1977, 99, 5225; (b) R. B. Calvert and J. R. Shapley, J. Am. Chem. Soc., 1978, 100, 7726; (c) M. Koike, D. G. Vander Velde and J. R. Shapley, Organometallics, 1994, 13, 1404.

16. L. Carlucci, D. M. Proserpio and G. D’Alfonso, Organometallics, 1999, 18, 2091.

17. M. E. García, A. Ramos, M. A. Ruiz, M. Lanfranchi and L. Marchiò, Organometallics, 2007, 26, 6197.

18. P. Legzdins, K. J. Ross, S. F. Sayers and S. J. Rettig, Organometallics, 1997, 16, 190.

19. M. A. Alvarez, M. E. García, D. García-Vivó, M. A. Ruiz and A. Toyos, Inorg. Chem., 2015, 54, 10536. 
20. M. A. Alvarez, M. E. García, M. E. Martínez, A. Ramos and M. A. Ruiz, Organometallics, 2009, 28, 6293.

21. (a) E. Delgado, J. C. Jeffery, N. D. Simmons and F. G. A. Stone, J. Chem. Soc., Dalton Trans., 1986, 869; (b) W. Sun, S. Yang, H. Wang, Y. Yin and K. Yu, Polyhedron, 1992, 11, 1143.

22. M. A. Alvarez, M. E. García, S. Menéndez and M. A. Ruiz, J. Organomet. Chem., 2015, 799-800, 147.

23. (a) A. J. Bridgeman, M. J. Mays and A. D. Woods, Organometallics, 2001, 20, 2932; (b) S. N. Konchenko, A. V. Virovets, S. V. Tkachev, V. I. Alekseev and N. V. Podberezskaya, Polyhedron, 1996, 15, 1221.

24. C. M. Alvarez, M. A. Alvarez, M. E. García, A. Ramos, M. A. Ruiz, C. Graiff and A. Tiripicchio, Organometallics, 2007, 26, 321.

25. M. A. Alvarez, M. E. García, M. A. Ruiz, A. Toyos and M. F. Vega, Inorg. Chem., 2013, 52, 7068.

26. G. B. Ritcher-Addo and P. Legzdins, Metal Nitrosyls, Oxford University Press, Oxford, U. K., 1992.

27. P. S. Braterman, Metal Carbonyl Spectra, Academic Press, London, U. K., 1975.

28. (a) C. J. Cramer, Essentials of Computational Chemistry, 2nd Ed., Wiley, Chichester, UK, 2004; (b) W. Koch and M. C. Holthausen, A Chemist's Guide to Density Functional Theory, 2nd Ed., Wiley-VCH, Weinheim, 2002.

29. L. Yu, G. N. Srinivas and M. Schwartz, J. Mol. Struct. (Theochem), 2003, 625, 215.

30. Since in the static structure the edge-bridging hydride is expected to have a significant coupling to the $\mathrm{W}$ atom to which it is bound, but negligible coupling to the second $\mathrm{W}$ atom, then the averaged value of $32 \mathrm{~Hz}$ would be indicative of a $\mathrm{W}-\mathrm{H}-\mathrm{Fe}$ coupling of some $64 \mathrm{~Hz}$, which is a sensible figure for a coupling in a edge-bridging hydride ligand.

31. B. J. Burkhart and R. L. DeKock, Comput. Theor. Chem., 2012, 994, 1.

32. M. A. Alvarez, M. E. García, D. García-Vivó, S. Melón, M. A. Ruiz and A. Toyos, Inorg. Chem., 2014, 53, 4739.

33. M. A. Alvarez, M. E. García, D. García-Vivó, M. T. Rueda, M. A. Ruiz, A. Toyos and M. F. Vega, Dalton Trans., 2017, 46, 10440.

34. B. Cordero, V. Gómez, A. E. Platero-Prats, M. Revés, J. Echevarría, E. Cremades, F. Barragán and S. Alvarez, Dalton Trans., 2008, 2832.

35. B. Alvarez, M. A. Alvarez, M. E. García and M. A. Ruiz, Dalton Trans., 2016, 45, 1937.

36. A. J. Carty, S. A. MacLaughlin and D. Nucciarone, in Phosphorus-31 NMR Spectroscopy in Stereochemical Analysis, J. G. Verkade and L. D. Quin, Eds., VCH, Deerfield Beach, FL, 1987, Chapter 16. 
37. J. Sánchez-Nieves, B. T. Sterenberg, K. A. Udachin and A. J. Carty, Can. J. Chem., 2003, 81, 1149.

38. M. E. García, D. García-Vivó and M. A. Ruiz, Organometallics, 2009, 28, 4385.

39. D. N. Duffy, M. M. Kassis and A. D. Rae, Acta Crystallogr., Sect. C, 1991, 47, 2343.

40. W. L. F. Armarego and C. Chai, Purification of Laboratory Chemicals, 7th ed., Butterworth-Heinemann, Oxford, U. K, 2012.

41. W. W. Herrmann, Angew. Chem., Int. Ed. Engl., 1974, 86, 335.

42. W. Strohmeier, Angew. Chem., 1964, 76, 873.

43. CrysAlis Pro, Oxford Diffraction Limited, Ltd., Oxford, U. K., 2006.

44. L. J. Farrugia, J. Appl. Crystallogr., 1999, 32, 837.

45. (a) G. M. Sheldrick, Acta Crystallogr., Sect. A, 2008, 64, 112; (b) G. M. Sheldrick, Acta Crystallogr., Sect. C, 2015, 71, 5.

46. A. G. Orpen, Dalton Trans., 1980, 2509.

47. M. J. Frisch, et al., Gaussian 03, Revision B.02, Gaussian, Inc., Wallingford, CT, 2004, see the ESI $\uparrow$ for the complete reference.

48. A. D. Becke, J. Chem. Phys., 1993, 98, 5648.

49. C. Lee, W. Yang and R. G. Parr, Phys. Rev. B, 1988, 37, 785.

50. P. J. Hay and W. R. Wadt, J. Chem. Phys., 1985, 82, 299.

51. (a) P. C. Hariharan and J. A. Pople, Theor. Chim. Acta, 1973, 28, 213; (b) G. A. Petersson and M. A. Al-Laham, J. Chem. Phys., 1991, 94, 6081; (c) G. A. Petersson, A. Bennett, T. G. Tensfeldt, M. A. Al-Laham, W. A. Shirley and J. Mantzaris, J. Chem. Phys., 1988, 89, 2193.

52. S. Portmann and H. P. Luthi, CHIMIA, 2000, 54, 766. 